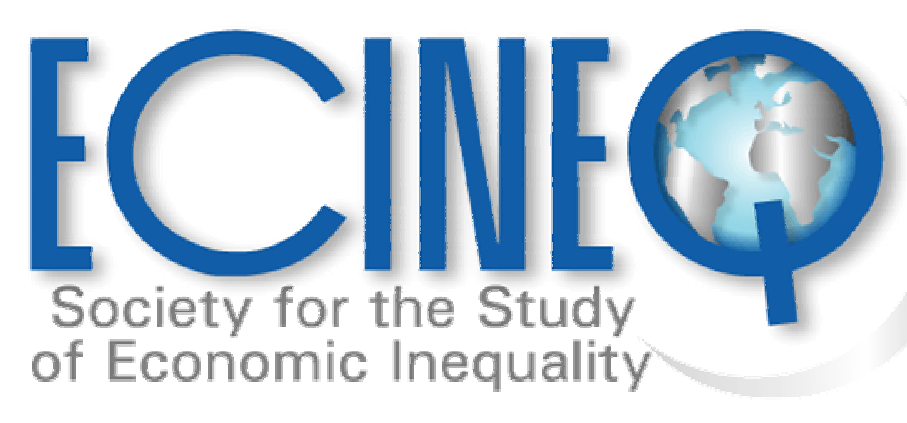

Working Paper Series

Education, Intergenerational Mobility and Inequality

Nathalie Chusseau

Joël Hellier

ECINEQ WP 2012 - 261 


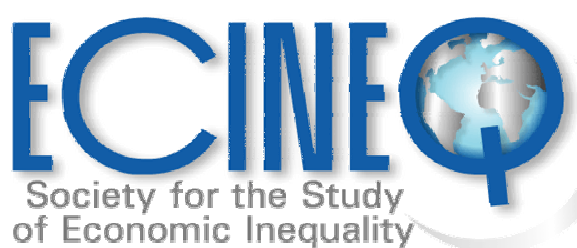

ECINEQ 2012 - 261

September 2012

www.ecineq.org

\title{
Education, Intergenerational Mobility and Inequality ${ }^{*}$
}

\author{
Nathalie Chusseau ${ }^{\dagger}$ \\ EQUIPPE, University of Lille 1 \\ Joël Hellier \\ EQUIPPE, Univ. of Lille 1, and LEMNA, Univ. of Nantes \\ in collaboration with: \\ Bassem Ben-Halima \\ EQUIPPE, University of Lille 1
}

\begin{abstract}
We review the economic literature on the impacts of the several dimensions of education upon intergenerational inequality persistency. It is firstly outlined that the critical increase in the population education level in all countries has not come with lower inequality. The basic tools of education and intergenerational mobility modelling are subsequently exposed (OLG, education functions, education decision making etc.). The following two theoretical sections analyse the cases in which education leads (i) to human capital convergence in the long term and (ii) to social stratification with the emerging of under-education traps (situations in which certain dynasties remain continuously under-educated). A simple modelling of both cases is proposed for two types of educational decisions, one based on the family expenditure on education and the other on the time spent for education. The factors that generate social stratification and under education traps are especially underlined. The empirical literature on the determinants of educational attainment and intergenerational mobility is finally reviewed.

This reveals the crucial impact of family backgrounds on educational attainment in all countries. It also demonstrates huge and lasting differences across countries in terms of intergenerational mobility.
\end{abstract}

Keywords: education, human capital, intergenerational mobility, social stratification.

JEL Classification: E24, I24, J24, J62.

\footnotetext{
* We wish to thank the French Research national Agency (ANR) for its financial support.

${ }^{\dagger}$ Contact details: Nathalie Chusseau: Nathalie.Chusseau@univ-lille1.fr.

Joël Hellier: joel.hellier@wanadoo.fr.
} 


\section{Introduction}

Since the early seventies, both the proportion in a generation of tertiary education graduates and the educational level of the working population have substantially increased in all developed countries as well as in most of the emerging economies. However more education has not meant more equality and the general upgrading of skills has coincided with growing within-country income inequality. Over the same period, intergenerational persistence of inequality has remained high in a large number of countries, and the differences in intergenerational mobility have remained significant across countries. In addition, several works reveal that intergenerational mobility is very low at both ends of the income and education spectrum. This shows (i) that under-education and poverty traps could exist, and (ii) that the same families constitute the best paid and the most educated group from one generation to the next. In a number of countries, the combination of intergenerational persistence (i.e., the hierarchy of families is maintained over time) and growing income and educational within-generation differences tend to create inegalitarian dynamics with a high social and family related determination.

Since the seminal work of Becker and Tomes (1976), economists have proposed a wide range of theoretical models portraying intergenerational educational dynamics within market economies. The early theoretical works predicted a convergence of all dynasties towards the same human capital level in the long term. Since this seemed at odds with observed developments, the analysis has subsequently shifted to the explanations of persistent intergenerational inequalities in education and of the genesis of under-education traps, i.e., situations in which certain dynasties remain unskilled from one generation to the next. There are many explanations for this: imperfections in the credit market, fixed costs of education, neighbourhood effects and local externalities, differences in altruism between families, structure of the educational systems etc. There are thus a number of factors that rule out any educational convergence of dynasties.

In line with the theoretical analyses, the empirical literature has attempted to quantify (i) the impact of parental characteristics on their children's income and educational attainment, and (ii) the influence of extra family determinants. This makes it possible to measure (i) intergenerational mobility and its variation over time, (ii) the different channels through which the family and parental backgrounds impact on the individuals' income and educational attainment, and (iii) the impact of different factors, particularly social and education policies, to prevent the widening of persistent inequalities due to educational divergence across 
dynasties. The empirical results confirm a crucial impact of the family backgrounds, but the impact critically differs across countries. Family characteristics have substantial impacts in the US, but their influence is much lower in Nordic countries. Both educational public expenditure and educational systems bear significant influences on human capital formation, albeit with different impacts from their different dimensions. In contrast, the neighbourhood effect and credit constraints have rather limited impacts. These may however significantly differ depending on the individual's social group.

Section 2 depicts the main developments and stylised facts in terms of educational attainment, education premium and intergenerational mobility over the thirty last years by focusing on the case of developed countries. Section 3 examines the bases of intergenerational human capital analyses, i.e., the education function, the educational decisions of individuals/families and the shape of education policies and systems. Section 4 presents the dynamic model(s) that predicts human capital convergence and its conditions. The reasons for the emergence of under-education trap and their modelling are examined in Section 5. Section 6 describes the empirical literature on the determinants of IM of income and education by examining its methodological issues and main results. We conclude in Section 7.

\section{Stylised facts}

Three main stylised facts may justify the issues examined in this chapter:

1) A general skill upgrading of the working population in advanced countries;

2) An increase in the skill premium and in skill inequalities.

3) A significant intergenerational persistence of social positions in a large number of advanced countries.

\subsection{General skill upgrading}

The educational level of the working population has substantially increased in all advanced countries since the 1960s. This can be seen from Figure 8.1 that depicts the share of the population over age 25 with tertiary education for six sets of advanced countries over the period 1950-2010. However, the periods and pace of skill upgrading can critically differ across countries, resulting in non negligible skill differences. 


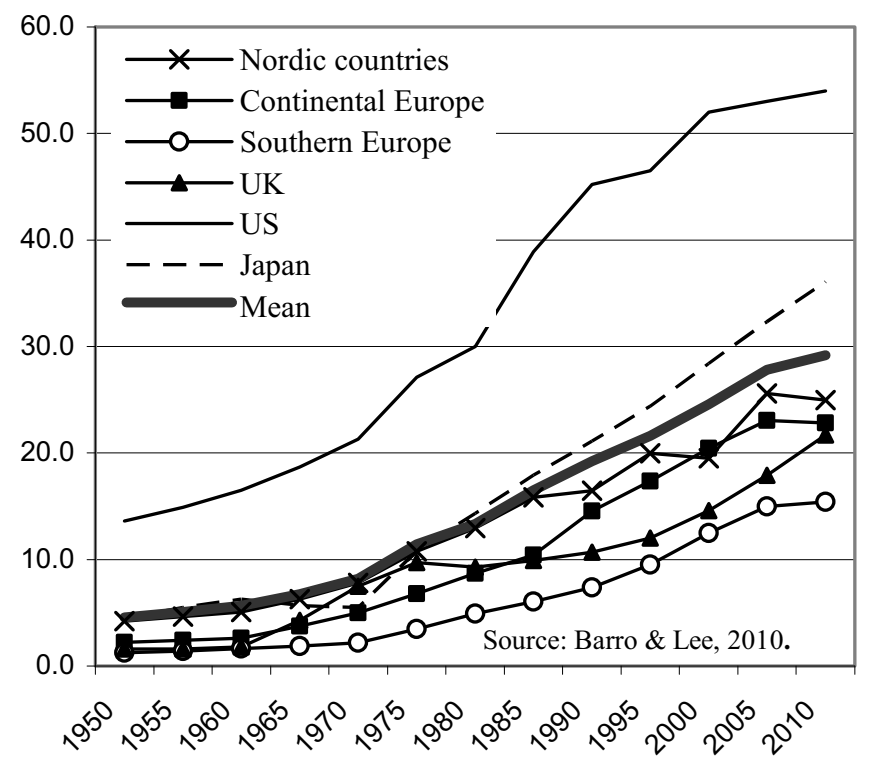

Fig 8.1: Share of the population (25 and over) with tertiary education

\subsection{Increasing inequality between skilled and unskilled workers}

The increase in inequality in advanced countries as well as in most of the emerging economies has been described and analysed in Chapters 1 and 2. This shows that skill upgrading has not been accompanied by a decrease in inequality either in advanced or in most of emerging countries. In addition, the coincidence of skill upgrading and higher inequality between skilled and unskilled workers can be interpreted in two ways. This can firstly show a divergence in the variations of the wage values of the different skill levels benefiting the highest skills. It can also stem from an increase in skill that is higher for the children from highly educated and affluent families than for those from little educated and poor families.

\subsection{Intergenerational mobility}

Intergenerational mobility can be broadly measured by considering transition matrices. The transition matrix $\left\{\alpha_{i j}\right\}$ provides the percentage $a_{i j}$ of individuals with the education level $j$ and whose parents possess the education level $i$ in the population, $\sum_{j} \sum_{i} \alpha_{i j}=1$. Then, $\hat{\alpha}=\sum_{j} \alpha_{j j}$ is the percentage of individuals who possess the same educational level as their parents, and $m=1-\hat{\alpha}$ measures intergenerational mobility. Identically, $a=\sum_{j>i} \alpha_{i j}$ is the percentage in the population of the individuals who possess an educational level higher than that of their parents, i.e., $a$ is a measure of ascending mobility, and $d=\sum_{j<i} \alpha_{i j}$ is a measure 
of descending mobility. Of course, such indicators provide broad and imperfect measures of mobility. In particular, they fail to account for the fact that mobility as well as upward mobility is more likely in countries in which a low proportion of the population was highly educated in the fathers' generation than in those where this represented a large proportion of the population. In addition, when everyone steps up the skills ladder, this general move must be excluded from the calculation to obtain an adequate measurement of social mobility.

Table 8.1 Intergenerational mobility indicators (2005)

\begin{tabular}{lccc}
\hline & Mobility indicator $m$ & Ascending mobility $a$ & Descending mobility $d$ \\
\hline France & 69 & 63.6 & 5.4 \\
Italy & 70 & 66.6 & 3.4 \\
Netherlands & 71 & 62.1 & 9.0 \\
Spain & 61.5 & 58.0 & 3.6 \\
Sweden & 80 & 74.2 & 5.7 \\
UK & 79.6 & 73.2 & 6.4 \\
\hline Source: own calculations from EU-SILC data, 2005, intergenerational module. 5 skill levels.
\end{tabular}

Table 8.1 depicts the mobility indicator $m=1-\hat{\alpha}$, and the upward and downward mobility indicators $a$ and $d$ for six advanced countries in 2005. Skill immobility concerns between 20 and 40 percent of the individuals and differences across countries are substantial. To measure social mobility it is however necessary to correct these coefficients by considering the general intergenerational skill upgrading. This would result in lower mobility. In addition, mobility can lead to higher inequality when upward mobility is larger in the already educated families than in the low educated ones. For the UK, Machin (2007) shows that the extension of tertiary education has been significantly higher in high skilled families than in low skilled families. For France, Cahuc et al. (2011) utilise the results of the PISA survey to diagnose that the increase in the education level of the population has been accompanied by a significant increase in educational inequality, particularly in the 2000 s.

\section{Intergenerational mobility analyses}

Intergenerational mobility has long been a crucial concern for sociologists. Since Becker and Tomes $(1976,1979)$, it has also become a relevant component of economic analysis. Even if intergenerational mobility is a multidimensional phenomenon, economists have put forward the transmission of human capital as a major determinant of the intergenerational transmission of income inequality. If intergenerational mobility depends on the intergenerational persistence of income differences between families and if individuals' incomes are essentially 
determined by their skill, then the acquisition of human capital is a key factor in intergenerational mobility. Education is thus at the core of this analysis.

In the economic literature, the choice for education is modelled by the combination of education functions and objective (utility) functions of individuals that result in a decision process inside the family. We now present the main characteristics of education functions and of this decision process.

\subsection{Education functions}

An education function determines the individuals' human capital by the combination of educational inputs. It is a production function of human capital.

Since we are concerned by intergenerational analyses, we define an individual by both her/his dynasty (succession of individuals linked by a parent-child relationship) and the generation $\mathrm{s}$ /he belongs to. We suppose overlapping generations (OLG). The family comprises two members, one parent and one child. In all cases, there is thus one individual only in each dynasty at each generation. We denote individual $(i, t)$ the $t$-th generation of dynasty $i$. We also assume that the number of dynasties $M$, and thus the number of families, remains constant.

Each individual lives three periods of time, being successively young, of working age and in retirement. When young, the individual cannot work and s/he lives at her/his parent's home who freely provides her/him with food and accommodation. Introducing a retirement period creates savings, which is necessary to fund children's education.

Let $h_{i t}$ be individual $(i, t)$ 's human capital. An education function can be represented by:

$$
h_{i t}=H\left(x_{i t}, z_{t}, h_{i t-1}\right)
$$

where $x_{i t}$ is a vector of characteristics of dynasty $i$ at period $t, z_{t}$ a vector of characteristics that are independent from the individual and her/his dynasty and that impact on individual $(i, t)$ 's human capital, and $h_{i t-1}$ the human capital of individual $(i, t)$ 's parent.

Remarks:

1. We assume that the shape of the education function does not vary with time; otherwise (8.1) would become $h_{i t}=H_{t}(\cdot)$.

2. Suppose that the vectors $x_{i t}$ and $z_{t}$ are constant over time. Then education function (8.1) determines a human capital intergenerational mobility function in which one individual's human capital directly and solely depends on her/his parent's human capital. 
3. When the education system consists of different cycles, there are several education functions corresponding to each cycle.

\section{Intra-family determinants}

The impact of intra-family (and thus intra-dynasty) factors upon one individual's human capital is captured in relation (8.1) by both the human capital of the parent $h_{i t-1}$ and by the vector $x_{i t}$ of the family characteristics.

As regards intra-family direct transmission of human capital and ability, two types of approach have been developed.

In the first (Becker \& Tomes, 1976, 1979, 1986), the child's education depends on her/his ability that comprises a genetically transmitted component (the parent's ability) plus a 'luck' random component. The education function is of the type $h_{i t}=H\left(a_{i t}\right.$, other determinants $)$, with the individual's ability $a_{i t}$ determined by dynamics $a_{i t}=\eta a_{i t-1}+\lambda_{i t}, \eta$ being the ability inheritance coefficient, $a_{i t-1}$ the parent's ability and $\lambda_{i t}$ the random luck. Assuming $0<\eta<1$, the initial ability level bears no impact on the dynasty's ability in the long term.

In a second type of approach (Galor \& Tsiddon, 1997), the child's education depends on an intra-family human capital externality, i.e., on the direct transmission of human capital inside the family. This comprises both the knowledge directly acquired from the parents and the transmission of capacities of reasoning and analysis, and thereby of the ability to capture the knowledge provided to the child by the educational system. This approach is the one selected in function (1).

Concerning the vector $x_{i t}$, four main family characteristics have been put forward:

- The first is the parents' expenditure on their children's education that depends on their income and wealth and on their altruism towards their children. When the parents' incomes depend on their human capital, which is typically the case, this provides an additional channel by which $h_{i t-1}$ impacts on $h_{i t}$. In a number of works, the impact of parents' human capital on their children's human capital solely depends on the money transfers from the former to the latter. These transfers can derive, either from altruism and bequest as in Galor \& Zeira (1993) and Maoz \& Moav (1999), or from children borrowing from their parents because of imperfections on the credit market as in Barham et al. (1995).

- The second determinant consists of local externality generated by neighbourhood effects (Benabou, 1993, 1994, 1996a,b,c; Durlauf 1994, 1996). If the families with similar education and income levels tend to gather in the same districts, then two mechanisms influence the children's educational level. Firstly, the children from educated families will benefit at school 
as well as in their private activities from human capital externalities from other children also belonging to educated families. In addition, schools will benefit from better facilities and better teachers in the prosperous districts where families pay more taxes.

- Thirdly, educated families may attach greater importance to education and be in this respect more altruistic towards their children's education than less educated families.

- Fourthly, educational attainment depends on the effort for education, on the schooling time and on the amount expended on education. The first typically depends on the individual's choice whereas the last two may depend on both the individual and the family decision.

Finally, other family characteristics can be added to the education function, particularly in empirical estimations: belonging to a native or an immigrant family, the sector in which the parents work, the number of people in the family, etc. These factors are less important for the theoretical long term analysis.

\section{Extra-family determinants}

There are several extra family determinants of the education function (vector $z_{t}$ in equation 8.1) and these primarily depend on the factors that influence schooling efficiency: public expenditure, teachers' performance which depends on their skill, wage, etc., number of children per class and per teacher, selection system, compulsory schooling time, structure of the educational system etc. As regards these factors, the major determinants are the level of public education expenditure and the manner in which this is allocated to the different priorities (education cycles, teachers, equipment etc.).

\section{A synthetic education function}

We focus on log-linear functions that present the dual advantages of being easy to utilise and permitting direct interpretations through elasticities. From the above discussion, a simple synthetic education function can be written:

$$
h_{i t}=\delta_{t} e_{i t}^{\lambda} s_{i t}^{\varepsilon}\left(h_{i t-1}\right)^{\eta}+\bar{h}, \lambda, \varepsilon, \eta<1
$$

with $\delta_{t}$ being the impact of public educational expenditure at period (generation) $t, e_{i t}$ the

private expense for education, and $s_{i t}$ the schooling time. The term $\left(h_{i t-1}\right)^{\eta}$ measures the intra-family human capital externality, and $\bar{h} \geq 0$ is the human capital without education.

In addition, the contribution of public expenditure to the individual's education $\delta_{t}$ is defined by: 


$$
\delta_{t}=\bar{\delta}\left(\frac{\tau Y_{t-1}}{P_{t}}\right)^{\gamma}, 0 \leq \gamma<1
$$

where $\tau$ is the tax rate that determines the proportion of the parents' generation total income $Y_{t-1}$ devoted to public education and $P_{t}$ the number of pupils of generation $t$.

By combining (2) and (3) and assuming $\bar{h}=0$, it comes:

$$
h_{i t}=\bar{\delta}\left(\frac{\tau Y_{t-1}}{P_{t}}\right)^{\gamma} e_{i t}^{\lambda} s_{i t}{ }^{\varepsilon}\left(h_{i t-1}\right)^{\eta}
$$

Function (8.4) is an education function that includes the main determinants of human capital formation.

It must be noted that functions (8.2) and (8.4) can be modified according to the selected educational scenario. For instance, if education is provided free of charge by the public authorities and the individual's choice limited to schooling time, then (8.2) becomes $h_{i t}=\delta_{t} s_{i t}^{\varepsilon}\left(h_{i t-1}\right)^{\eta}$. In contrast, when the schooling time is given and one individual's human capital depends on her/his financial effort for education, then (8.2) becomes $h_{i t}=\delta_{t} e_{i t}^{\lambda}\left(h_{i t-1}\right)^{\eta}$. Finally, an education system can comprise several education functions that portray different educational cycles.

\subsection{The education decision}

The education decision can be taken, either by the parents (as in Gradstein \& Justman, 2002), or by the individuals themselves, or by the combination of parents and children decisions (this is particularly the case when the children's education decisions depend on their parents' bequest decision as in Galor \& Zeira, 1993, and Maoz \& Moav, 1999). We shall focus on the last two cases in which individuals participate in their education decision.

Henceforth, we suppose that the economy produces one good with the technology $Y_{t}=\sum_{i=1}^{M} h_{i} \theta_{i}$, where $h_{i}$ is individual $i^{\prime} \mathrm{s}$ human capital and $\theta_{i}$ her/his working time. For simplicity, total factor productivity is standardised at 1 and the price of goods is unity. In pure competition with zero profit, the real wage per unit of human capital $\times$ working time is 1 and individual $i^{\prime} \mathrm{s}$ income $h_{i} \theta_{i}$. Individual $i$ supplies $\theta_{i}=1-s_{i}$ units of working time, $s_{i}$ being her/his schooling time when adult $\left(0 \leq s_{i} \leq 1\right)$. 
Individuals adopt the education strategy that maximises their lifetime income, which is thus their objective function. They subsequently distribute this income between consumption at their different life periods (and possibly bequest).

Several models of schooling decision are possible depending (i) on the education scenario and (ii) on the decision setting characteristics.

We consider two education scenarios. In the first, education is limited to youth and individuals must pay for schooling. In the second, basic schooling is freely provided to the young, and the individual can allot a proportion of her/his active period for further education. Further education is also free so that the only cost of schooling is the opportunity cost of not working. Of course, combinations of these two scenarios are possible. In particular, the choice of schooling time can incur fixed and/or variable costs of education. Finally, during their senior period of life, individuals have retired and spend the funds they have saved during their working period. This is a prerequisite in order to ensure that individuals can borrow the money they need for subsistence during their schooling time and to pay their school fees.

Both education scenarios lead to different decision models. In addition, the decision depends on the young people's access to the credit market.

When the youth period is fully devoted to education and adult time to work, and when human capital depends on private education expenditure, the individual's decision is related to the amount of money s/he spends on education. With a perfectly competitive credit market, the young individual determines the expense for education by maximising her/his income as an adult subject to the education function $h_{i t}=\delta_{t} e_{i}^{\lambda}\left(h_{i t-1}\right)^{\eta}$. If a young person has no access to credit, s/he must receive education funding from her/his family, either as a loan, or as a gift. The decision is then shared between the young individual and her/his parent and the maximisation programme depends on the conditions for receiving the parents' funding. In particular, a young can be restricted by the amount of funding provided by her/his parent.

Assume now that individuals divide her/his active time of length 1 between schooling and work, that education is freely provided, and that the credit market is perfectly competitive. Then individual $(i, t)$ chooses the schooling time $s_{i t}$ that maximises her discounted lifetime income $\int_{s_{i t}}^{1} h_{i t} \exp [-r x] d x$ subject to the education function $h_{i t}=\delta_{t} s_{i t}{ }^{\varepsilon}\left(h_{i t-1}\right)^{\eta}+\bar{h}$. If there is a fixed cost of education, this cost must be subtracted from the lifetime income when $s_{i t}>0$. If individuals have no access to the credit market, the education decision depends on her/his parent's loan or/and bequest. 
From the above discussion, it is clear that the family characteristics have a crucial impact on educational choice. The related intergenerational dynamics can produce very different outcomes in the long term.

\subsection{Long term human capital profiles}

To provide a very simple description of the long term human capital dynamics, let us suppose that all the determinants of the education function are constant except those that depend directly or indirectly on the parent's human capital. Then, the education function can be written $h_{i t}=H\left(h_{i t-1}\right)$. Figure 8.3 describes several possible shapes of this function.

Figure 8.3(a) depicts the case of a continuous, monotonically increasing and concave function. Then, all the dynasties tend towards the stable steady state $\hat{h}$ in the long term. In Figure (b) the function is continuous, monotonically increasing and convex. There are two steady states only one of which is stable. All the dynasties situated on the human capital interval $\left[0, h_{2}\left[\right.\right.$ tend towards the stable steady state $\hat{h}_{1}$ that is an under-education trap, whereas all the dynasties whose human capital is higher than $h_{2}$ show their human capital to tend towards infinite in the long term. The continuously increasing education function depicted in Figure (c) presents fives steady states, three of which are stable. In the long term, such an education function typically results in a three-level social stratification of the population. Finally, Figure (d) pictures a non continuous increasing function. This can be interpreted as a two-level education system in which only the children with parents' human capital higher than $\bar{h}$ are authorised to move up the higher level. This defines two stable steady states ( $\underline{h}$ and $\hat{h}$ ) and thus a two-groups social stratification with the under-education trap $\underline{h}$ when $\underline{h}<\bar{h}$. 

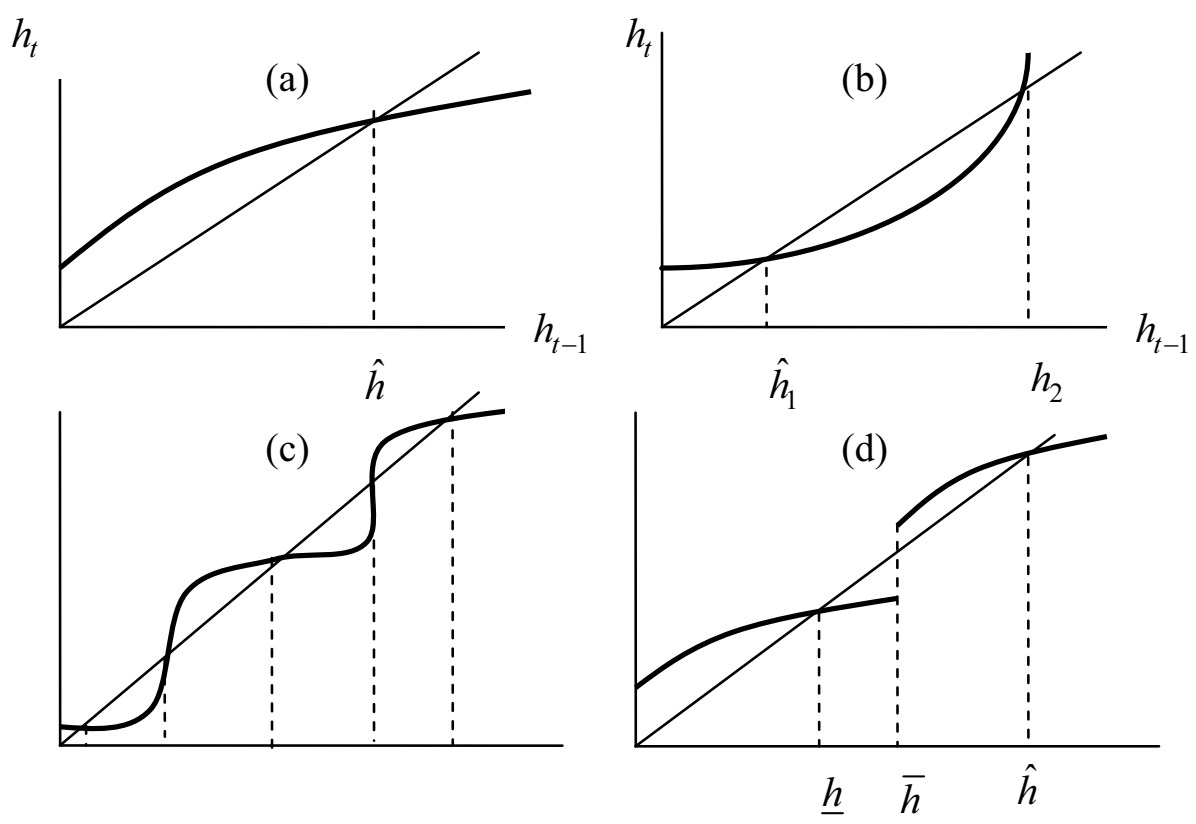

Figure 8.3: Shapes of education function and steady states

Among the four shapes depicted in Figure 8.3, only the first produces in a convergence of all dynasties towards a unique human capital steady state, which ensures equality in the long term. This case has been initially prioritized by the economic analysis.

\section{Long term skill convergence}

Becker \& Tomes (1979) were the firsts to build an intergenerational model that leads to human capital convergence of all the dynasties. This first contribution has been questioned because of certain unrealistic assumptions, particularly the hypothesis of perfectly competitive credit market. Loury (1981) and Becker \& Tomes (1986) have shown that the convergence is maintained with imperfect credit markets, with however a slow down of the convergence process.

We now present the dynamics of convergence in the two different models defined in subsection 8.3.2.

\subsection{The basic convergence models}

The basic model assumes a perfectly competitive credit market. Consequently, everyone can borrow money at the current interest rate. We show that, when the education function is concave, intergenerational dynamics result in the convergence of all dynasties towards the same human capital level. This is demonstrated for the two aforementioned decision models, i.e., (i) when the decision involves the expense for education and (ii) when it concerns schooling time. In both cases, we assume a utility function $u=(1-\sigma) \log c_{a}+\sigma \log c_{r}$, where 
$c_{a}$ and $c_{r}$ are respectively the consumption during the working (adult) and retirement periods. Thus, the individual allocates the proportion $\sigma$ of her/his lifetime income to consumption during the retirement period. Since young individuals receive free food and accommodation from their parents, the utility function only relates to consumption during the adult and retirement periods. Finally, from the simple technology presented in subsection 2.2., the real wage per unit of human capital $\times$ working time is 1 .

\section{The expense for education scenario}

Everyone possesses a basic human capital that without loss of generality is equal to 1 . In addition, individual $(i, t)$ can increase her/his human capital by the amount $h_{i t}$ that depends on her/his private expenditure on education. Henceforth we call human capital the value $h_{i t}$ above the basic endowment 1 . Human capital $h_{i t}$ is determined by the education function $h_{i t}=\delta e_{i t}{ }^{\lambda}\left(h_{i t-1}\right)^{\eta}$, with $e_{i t}$ the educational private expense and $h_{i t-1}$ the parent's human capital.

Being young, individuals determine their optimal human capital levels and they borrow the funds necessary to pay for their education. When they are working adults, they allocate their income from working (i) to refund their loans, (ii) to consume, and (iii) to save for their retirement time. When retired, they consume their savings.

The individual firstly chooses the education strategy that maximises her/his lifetime income. S/he subsequently distributes this income between the consumptions during her/his working and retirement periods by maximising the utility function.

Individual $(i, t)$ maximises her/his discounted net lifetime income $I_{i t}=1+h_{i t}-\rho_{t} e_{i t}$ subject to the education function $h_{i t}=\delta e_{i t}{ }^{\lambda}\left(h_{i t-1}\right)^{\eta}$, with $\rho_{t} \equiv 1+r_{t}$ and $r_{t}$ the interest rate at which generation $t$ borrows from generation $(t-1)$, and thus the return to saving for generation $(t-1)$. This determines the optimal educational expense:

$$
\hat{e}_{i t}=\left(\frac{\lambda \delta}{\rho_{t}}\right)^{1 /(1-\lambda)}\left(h_{i t-1}\right)^{\eta /(1-\lambda)}
$$

The related intergenerational human capital dynamics is defined by:

$$
h_{i t}=\delta^{1 /(1-\lambda)}\left(\frac{\lambda}{\rho_{t}}\right)^{\lambda /(1-\lambda)}\left(h_{i t-1}\right)^{\eta /(1-\lambda)}
$$

Assuming that $\eta+\lambda<1$, function (8.6) is concave as depicted in Figure 8.4 (note that this curve shifts with time as $\rho_{t}$ is moving): 


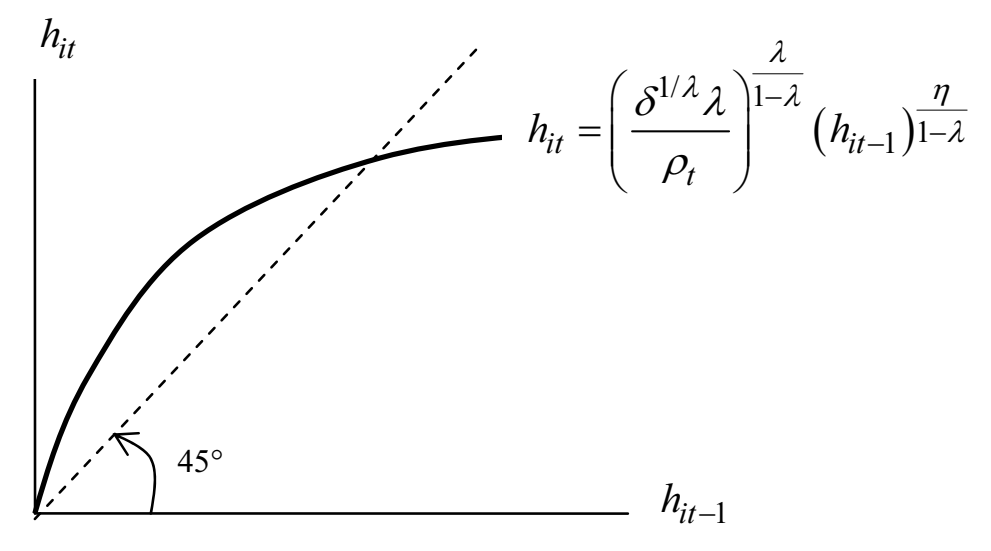

Figure 8.4: Intergenerational human capital mobility

Finally, the interest rate $r_{t}$ is determined by equalising the demand for credit of generation $t$ and the supply of credit of generation $t$-1 (see Appendix 1).

Such an economy tends towards a steady state in which the interest rate remains constant and all dynasties have he same educational expense $\hat{e}$ and the same human capital $\hat{h}$, and thus the same lifetime income (see Appendix 1 for the determination of the steady state).

A simple configuration of this general case is when the interest rate is nil, i.e., $r_{t}=0, \forall t$. This happens when, at each generation, the parents' total savings are higher than the children total demand for credit for $r=0$, thereby resulting in $r=0$ at equilibrium. Then, the individual's educational expense is $e_{i t}=\left(\lambda \delta\left(h_{i t-1}\right)^{\eta}\right)^{1 /(1-\lambda)}$, the related intergenerational human capital dynamics is $h_{i t}=\left(\delta \lambda^{\lambda}\left(h_{i t-1}\right)^{\eta}\right)^{1 /(1-\lambda)}$ and the human capital steady state to which all dynasties converge is $\hat{h}=\delta^{1 /(1-\lambda-\eta)} \lambda^{\lambda /(1-\lambda-\eta)}$

\section{The schooling time scenario}

As they are young, all individuals receive a freely provided basic education that ensures a basic human capital level 1 . They subsequently divide their active period of length 1 between further education and working in the proportions $s_{i t}$ and $\left(1-s_{i t}\right)$, subscript it indicating the individual's dynasty and generation. Further education being provided free of charge, the only related cost is the opportunity cost of not working. The further education function is $h_{i t}=\delta s_{i t}{ }^{\varepsilon}\left(h_{i t-1}\right)^{\eta}$ and we suppose that $h_{i 0}>0, \forall i=1 \ldots M$, which is the condition for education to be effective for everyone at the initial time. As above, we henceforth call human capital the value $h_{i t}$. 
Individual $(i, t)$ firstly chooses the education time $s_{i t}$ that maximises her/his income $I_{i t}=\left(1-s_{i t}\right)\left(1+h_{i t}\right)$ subject to the education function $h_{i t}=\delta s_{i t}{ }^{\varepsilon}\left(h_{i t-1}\right)^{\eta}$. The individual subsequently allocates this income to the consumptions of both periods of her/his adult life.

The maximisation of income determines the optimal schooling time $s_{i t}$ that is an increasing function of the parent's human capital $h_{i t-1}$ (Appendix 2). It can be shown (Appendix 2) that all the $s_{i t}$ tend towards the same steady state value $\hat{s}$ and thereby all dynasties tend towards the same human capital steady state $\hat{h}=\left(\delta \hat{s}^{\varepsilon}\right)^{1 /(1-\eta)} \cdot 1$

In both cases under analysis, i.e., when the individual's decision involves the education expense and when it concerns schooling time, we have shown that the optimal decision generates the convergence of all dynasties towards the same steady state human capital. We could determine the same outcome by combining these two shapes of decision.

\subsection{Credit constraint and low mobility}

In a number of situations, the existence of an imperfect credit market does not eliminate the convergence of dynasties towards the same human capital, but it slows down the transition process to the steady state. This was firstly shown by Loury (1981) and Becker \& Tomes (1986). Such a situation is called by Piketty (2000) a low mobility trap.

There are several means of including credit market imperfections in the education scenarios. The simplest way consists in assuming a risk premium that is paid by children from poor families. As income increases with human capital, then the higher the parents' human capital, the lower the risk premium and thus the interest rate paid by their children. A more restrictive assumption is to suppose that young people have no access to the credit market. Their funding for education can thus be carried out, either by borrowing directly from their parents, or through parents' bequests that depend on intra-family altruism.

\section{Higher risk premium for children from poor families}

When the risk premium is a decreasing function of the parent's income, the unit cost of education is higher for children from poorly educated families, who therefore reduce their education. This slows the transition to the steady state down, albeit without preventing the convergence of all dynasties towards the same human capital steady state. The reason for this

\footnotetext{
${ }^{1}$ The case presented here implicitly assumes that individuals can borrow with a zero interest rate. The same outcome may be shown by assuming non-zero interest rates (proof available upon request).
} 
is simple. Even if the payment of a risk premium reduces education, it does not prevent the increase of human capital from generation to generation. Thus, the risk premium decreases with each generation until the moment when the dynasty reaches the human capital with a zero risk premium. From this point, the dynasty is on the convergence path without risk premium $^{2}$.

\section{Parents help their children}

Children have no access to the banks but they can, either borrow from their parents, or receive bequests from them.

Let us firstly suppose that parents save for their retirement period and can thereby lend to their children at the current interest rate (Barham et al., 1995). This can be justified by the fact that, unlike the banks, they have access to information about their children's ability. The children firstly decide on their optimal education expense by accounting for the interest rate, which determines their demand for credit. Two cases can then be distinguished. In the first, the parent's savings are sufficient to provide the child with the funds they want to borrow. For them, there is thus no difference with the situation of perfect credit market. However, there is another possible case in which the parent's savings are too small to meet their child's demand for a loan. The child is thus constrained in her/his education, which result in lower and suboptimal human capital. The children in this situation are those from families where the parents' human capital and income are low and generate savings too small to fund their children's optimal schooling. Even if they are restricted in their education, these dynasties will sooner or later converge to the same steady state human capital as the unconstrained ones. This is because the human capital and income increases from one generation to the next even for the constrained dynasties, thereby releasing the saving constraint. From a certain generation, the constraint is dispelled and the dynasty can implement its optimal schooling decision.

The same type of scenario can be applied in the case of bequests based on parents' altruism. As in Galor and Zeira (1993) ${ }^{3}$, we suppose a paternalist altruism in which a bequest to their children is inserted into the parents' utility function and we denote $b_{i t}$ the bequest received by individual $(i, t)$ from her/his parent. It can be easily shown that this scenario is very much like the expense for education scenario in subsection 8.4.1. Individual $(i, t)$

\footnotetext{
${ }^{2}$ Note that the human capital steady state can be attained before the risk premium becomes zero, which however does not prevent the convergence to this steady state.

${ }^{3}$ Unlike Galor \& Zeira, we do not assume here a fixed cost of education that creates an under-education trap.
} 
maximises her/his net adult income $I_{i t}=1+h_{i t}+\rho_{t}\left(b_{i t}-e_{i t}\right)$ subject to the education function $h_{i t}=\delta e_{i t}{ }^{\lambda}\left(h_{i t-1}\right)^{\eta}$ and to the bequest constraint $e_{i t} \leq b_{i t}$. As $b_{i t}$ is exogenous for individual $(i, t)$, income maximisation results in the same optimal education expense as in Relation (8.5). Here again, two cases are possible. First, if $\hat{e}_{i t} \leq b_{i t}$ then the individual can fund her/his optimal schooling decision. Second, if $\hat{e}_{i t}>b_{i t}$ then the individual's education is constrained by her/his parent's bequest and lower than its optimal value corresponding to $\hat{e}_{i t}$. Here again, this constraint tends to disappear because, as human capital and income increase from generation to generation, so does the bequest, which releases the funding constraint ${ }^{4}$.

\section{Under-education traps}

In the models presented in Section 8.4, the human capital intergenerational dynamics causes all dynasties to converge to the same human capital steady state in the long term. This is conditioned by the concavity of the education function that links the individual's human capital to the human capital of her/his parent. However, empirical evidence seems to confirm the existence of under-education traps, i.e., situations in which the successive generations belonging to the same dynasty remain unskilled. Continuously convex education functions do not provide a convincing explanation for this because they are at odds with both logic and empirical evidence. Firstly, such functions mean that human skill tends towards infinite and that this skill upgrading is continuously accelerating, which is clearly unrealistic. Secondly, all empirical works show that the elasticity of the individuals' human capital with respect to their parents' human capital is lower than 1.

An under-education trap (henceforth UET) is a situation in which certain dynasties remain under-educated from one generation to the next. UET can be permanent (i.e., these dynasties are indefinitely under-educated) or transitory (then, all the dynasties leave the trap sooner or later). The economic literature has put forward several reasons for the emergence of undereducation traps. In what follows, we discuss five possible explanations: a fixed cost of education; imperfect credit market combined with another constraint; S-shaped education functions; local externalities; the structure of the education system.

\footnotetext{
${ }^{4}$ This is conditioned by the intergenerational increase in the bequest to be higher than the intergenerational increase in demand for funding, which is typically the case for 'normal' utility and education functions
} 


\subsection{Fixed cost of education}

Since the articles of Galor \& Zeira (1993) and Barham et al. (1995), the existence of a fixed cost of education has been recognised as generating under-education traps. Unlike both these models that assume imperfections on the credit market (and altruism in the case of Galor \& Zeira), we show here that the existence of a fixed cost of education is a sufficient condition for generating an UET. For this purpose, we place ourselves in the most favourable situation in terms of borrowing, i.e. a zero interest rate, and we determine the impact of inserting a fixed cost of education into both models developed in sub-section 3.1.

Let us firstly consider the model where young individuals decide on their education expense in which we introduce the additional assumption of a fixed cost of education $\bar{k}$. With $r_{t}=0$ (and thus $\rho_{t}=1$ ) the optimal expense of individual $(i, t)$ who decides being educated is $e_{i t}=\left(\lambda \delta\left(h_{i t-1}\right)^{\eta}\right)^{1 /(1-\lambda)} \quad($ Relation 8.5$)$ and her/his resulting income $\tilde{I}_{i t}=1+h_{i t}-e_{i t}-\bar{k}$. If $\mathrm{s} /$ he does not educate her/himself, her/his income is 1 . Thus, s/he decides to be educated only if $\tilde{I}_{i t}>1$. The condition for this is $h_{i t}-\left(\lambda \delta\left(h_{i t-1}\right)^{\eta}\right)^{1 /(1-\lambda)}>\bar{k}$. It can easily be shown ${ }^{5}$ that there is a unique value $\underline{h}=\left(\frac{\bar{k}^{1-\lambda}}{\delta(1-\lambda)^{1-\lambda} \lambda^{\lambda}}\right)^{1 / \eta}>0$ of their parents' human capital below which individuals choose not to educate themselves, and above which they choose to be educated. Since the non educated individuals have a human capital $h=0$, all the descendants of those who opt for no education will also remain non educated. As a consequence, all the dynasties with a human capital lower than $\underline{h}$ at the first generation will remain indefinitely non educated, and all the dynasties with an initial human capital higher than $\underline{h}$ will remain educated and converge to the steady state $\hat{h}=\left(\delta \lambda^{\lambda}\right)^{1 /(1-\lambda-\eta)}$. This results in a two-group social stratification with an under-education trap.

Let us now add a fixed cost of education $\bar{k}$ to the model in which individuals choose their schooling time when they become adults. The optimal schooling time of educated individuals $\hat{s}_{i t}$ is the same as in sub-section 8.4.1. (The schooling time scenario), i.e.,

\footnotetext{
$5 \quad$ Inserting $\quad h_{i t}=\delta e_{i t}^{\lambda}\left(h_{i t-1}\right)^{\eta} \quad$ and $\quad e_{i t}=\left(\lambda \delta\left(h_{i t-1}\right)^{\eta}\right)^{1 /(1-\lambda)}$ into $\quad h_{i t}-\left(\lambda \delta\left(h_{i t-1}\right)^{\eta}\right)^{1 /(1-\lambda)}>\bar{k} \quad$ yields $h_{i t-1}>\underline{h}=\left(\bar{k}^{1-\lambda} / \delta(1-\lambda)^{1-\lambda} \lambda^{\lambda}\right)^{1 / \eta}>0$.
} 
$\hat{s}_{i t}=s\left(h_{i t-1}\right), \partial s / \partial h_{i t-1}>0 \quad$ (Appendix 2), which generates the net income $I_{i t}=\left(1-\hat{s}_{i t}\right)\left(1+\delta \hat{s}_{i t}{ }^{\varepsilon} h_{i t-1}{ }^{\eta}\right)-\bar{k}$. The individual chooses education if this income is higher than 1 , i.e., $\left(1-\hat{s}_{i t}\right) \delta \hat{s}_{i t}{ }^{\varepsilon} h_{i t-1}{ }^{\eta}-\hat{s}_{i t}>\bar{k}$. This inequality determines a threshold value of the parents' human capital $\underline{h}$ above which individuals opt to be educated, and below which they choose not to be educated. Once one of its generations has selected no education, a dynasty remains indefinitely non educated. Thus, all the dynasties such that their initial human capital endowment is lower than $\underline{h}$ remain indefinitely non educated, and all those with an initial human capital higher than $\underline{h}$ converge to the steady state human capital $\hat{h}=\left(\delta \hat{s}^{\varepsilon}\right)^{1 /(1-\eta)}$. Once again, this generates dual group stratification with an under-education trap.

\subsection{Credit market imperfection combined with another constraint}

When young individuals have no access to bank credits, they must obtain their education funding from theirs parents, either through loans, or through bequests.

It can be firstly noted that this provides an additional mechanism through which a fixed cost of education can generate an under-education trap: if the parents' saving or bequest is lower than the fixed cost of education, then individuals cannot fund their schooling (Barham et al., 1995, present such a model based on parents' loans, and Galor \& Zeira, 1993, a model of this type with parental altruism).

Without fixed education cost, we have shown in subsection 8.4.2. that the lack of access to bank loans does not abolish human capital convergence when parents can finance education, even if their funding capacity is lower than their children demand for credit. However, this convergence can be impeded when certain factors prevent parents from saving or providing bequests. This can be the case of a minimum consumption level under which individuals spend all their income in order to consume. Of course, such a constraint supposes the OLG scenario to be modified. In particular, if individuals cannot save because their income is totally spent on consumption, they thereby have no resources to consume when they retire. Two types of modification can be considered. The first is to include a public retirement pensions scheme in the model, and the second to assume that individuals can work throughout their lives.

Moav \& Neeman (2012) provide an additional explanation for low saving rates in lowincome families. These families spend part of their incomes in conspicuous consumptions for economic status reasons whereas richer and educated families do not need to signal their 
status by this way. The equilibrium generated by the authors is characterised by an increasing marginal propensity to save that might generate poverty traps.

In summary, any constraint that prevents certain parents from saving makes their children fall into an under-education trap when imperfections prevent them from borrowing on the credit market.

\subsection{S-shaped education functions}

We have already indicated that the hypothesis of a continuously convex education function should be rejected. However, there is no reason to assume that this function is continuously concave. A noteworthy case analysed by Galor \& Tsiddon (1997) is that of an S-shaped education function.

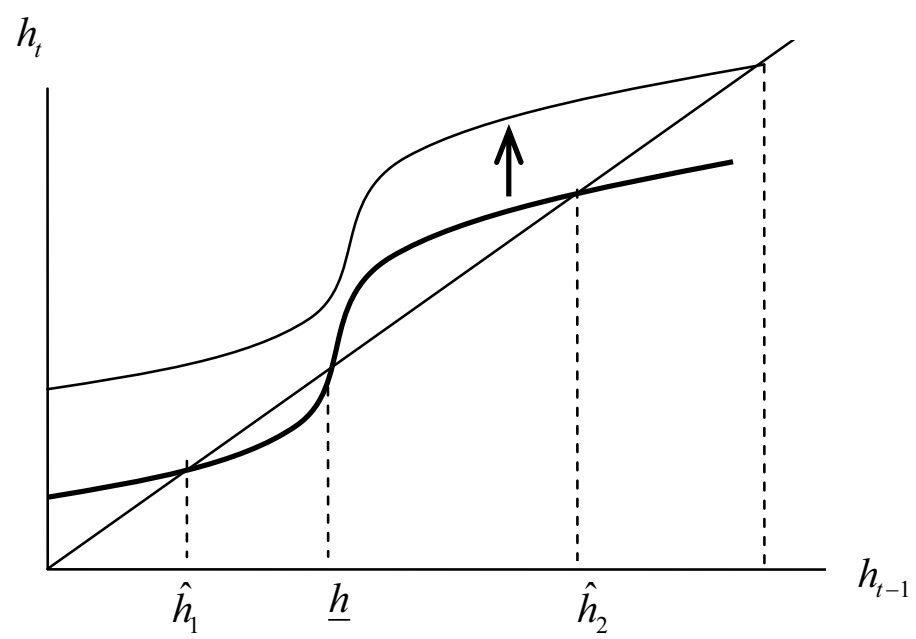

Figure 8.5: S-shaped education function

Let us suppose that the education function is that depicted by the bold curve in Figure 8.5. This generates three human capital steady states $\left(\hat{h}_{1}, \underline{h}\right.$ and $\left.\hat{h}_{2}\right)$, only two of which are stable $\left(\hat{h}_{1}\right.$ and $\left.\hat{h}_{2}\right)$. All the dynasties with an initial human capital below $\underline{h}$ converge to the loweducation steady state $\hat{h}_{1}$, and all those with an initial human capital above $\underline{h}$ to the higheducation steady state $\hat{h}_{2}$. This creates social polarization with a highly educated and highly paid social group, and a little educated and poorly paid social group that gathers the dynasties remaining in the under-education trap. Nevertheless, Galor \& Tsiddon (1997) show that this social stratification can be transitory.

For the UET to be transitory, a sufficient condition is that the S-shaped education function moves upwards with time, thereby moving the convex part of the curve above the $45^{\circ}$ line. This can result, either from a human capital externality in the education function or from an 
endogenous increase in the resources allocated to education. Both cases can be simply modelled by assuming an education function $h_{i t}=\delta_{t} H\left(h_{i t}\right)$, with $H(\bullet)$ being S-shaped and $\delta_{t}$ increasing with time. In the case of a human capital externality in the education function, we have $\delta_{t}=\delta\left(\bar{h}_{t-1}\right), \partial \delta / \partial \bar{h}_{t-1}>0$, with $\bar{h}_{t-1}$ being the average human capital of the parents' generation. In the case of increasing resources for education, then $\delta_{t}=\delta\left(\tau I_{t-1}\right)$, $\partial \delta / \partial\left(\tau I_{t-1}\right)>0$, where $\tau I_{t-1}$ are the levies allowed for education, $\tau$ the tax rate and $I_{t-1}$ the total income of the parents' generation that increases with the education level of the population. In both cases, an increase in the average human capital level of the economy raises $\delta_{t}$ and displaces the S-shaped curve upwards. Once this upward move has placed the convex part of the curve above the $45^{\circ}$ line, the UET disappears.

It must however be underlined that the upward move of the S-shaped curve must be sufficiently high to cause the UET to vanish. Let us start from the bold curve in Figure 8.5. If a large number of parents are initially located between the human capital values $\underline{h}$ and $\hat{h}_{2}$, then the curve moves upwards and this deletes the UET. In contrast, when a large number of parents are initially situated between $\hat{h}_{1}$ and $\underline{h}$, then the curve moves downwards and the society tends towards a two-segment stratification with an UET and a highly educated social group. In Galor and Tsiddon (1997), the persistence of the UET is however prevented by the shape of technological change function.

\subsection{Local externalities}

The impact of local externalities and neighbourhood effects upon education, intergenerational mobility and persistent inequality has been particularly analysed by Benabou (1993, 1994, 1996a,b,c) and Durlauf (1994, 1996). Their models show that the existence of local human capital externalities can explain the propensity of individuals to gather according to their skill and income levels, which generates educational advantages for the rich and educated families and persistent inequality across dynasties.

There are several reasons why individuals with similar education levels tend to congregate in the same district. Firstly, the existence of human capital externalities incites parents to prefer areas with highly educated residents to boost their children's education. Secondly, the districts with highly educated and rich residents perceive more levies, which improve education and public services. Thirdly, network effects improve professional opportunities for both parents and children in rich areas. Such gathering tends to exclude low educated and 
poor people because the rich are ready to pay more for their houses and accommodation so as to stay together. This causes local segregation with the coexistence of rich areas with highly educated residents on the one side, and poor areas with poorly educated residents on the other.

A very simple way to model the impact of local stratification is to assume an education function $h_{i t}=\bar{\delta}\left(\tau \bar{h}_{d, i t-1}\right)^{\theta}\left(\bar{h}_{d, i t-1}\right)^{\varepsilon}\left(h_{i t-1}\right)^{\eta}$, with subscript $d$ indicating the district where family $i$ lives. Individuals educate themselves when young and they earn an income equal to their human capital once they become adults. All children follow the education freely provided by the district and financed by a tax on the district families (parents) income at rate $\tau$. The value $\bar{h}_{d, i t-1}=\bar{h}_{d, t-1}$ is the average human capital in the district where dynasty $i$ lives at generation $t-1$. Hence, $\tau \bar{h}_{d, i t-1}$ is the tax per pupil in district $d$ at generation $t-1$. Thus, $\left(\tau \bar{h}_{d, i t-1}\right)^{\theta}$ depicts the impact of public expenditure on education at the district level, and $\left(\bar{h}_{d, i t-1}\right)^{\varepsilon}$ the local human capital externality (neighbourhood effect). We do not model here the stratification process that is endogenously generated by the families' utility maximisation (see, e.g., Benabou, 1994). To simplify, we assume a two groups (high and low educated, i.e., $d=H, L)$ local stratification that arises at the initial time (generation 0 ) and that is maintained from generation to generation. There are thus two education functions, i.e., $h_{i t}=\bar{\delta} \tau^{\theta}\left(\bar{h}_{L, t-1}\right)^{\theta+\varepsilon}\left(h_{i t-1}\right)^{\eta}$ for low educated dynasties and $h_{i t}=\bar{\delta} \tau\left(\bar{h}_{H, t-1}\right)^{\theta+\varepsilon}\left(h_{i t-1}\right)^{\eta}$ for the highly educated ones, with $\bar{h}_{H, t-1}>\bar{h}_{L, t-1}$. It is clear that, compared to the situation with no stratification, intergenerational human capital growth slows for the low educated group, and accelerates in the highly educated one.

In addition, the maintaining of social stratification in the long term depends on the coefficients of de education function. If $\theta+\varepsilon+\eta<1$, both groups tend towards the same human capital steady state $\hat{h}=\left(\bar{\delta}^{\theta}\right)^{\frac{1}{1-\theta-\varepsilon-\eta}}$. The convergence is thus realised, but it is slowed down by local stratification. If $\theta+\varepsilon+\eta>1$, the human capital dynamics typically causes a the division of the society into two groups, one with low education ${ }^{6}$ and the other with a continuously increasing human capital.

\footnotetext{
${ }^{6}$ Within the simple framework presented here, this group tends towards zero human capital, but it is easy to make it converge to a positive human capital level through a slight modification of our assumptions.
} 


\subsection{Education systems}

Several empirical works have shown that graduates from selective, high level colleges do have better labour market performances (Daniel et al., 1995, for Canada; Ono, 2004, for Japan; Dale \& Krueger, 2002, for the US). Other empirical works underline the impact of education systems upon the differences in occupational attainment (Shavit and Muller, 2000) and in the transitions from school to work between countries (Kerckhoff, 2000).

Since Weber and Durkheim, the impact of the very structure of education systems on the society, and particularly on social stratification, has been systematically analysed by sociologists (Weber 1906; Sorokin, 1959; Anderson, 1961; Bourdieu \& Passeron, 1970; Baudelot \& Establet, 1971; Boudon, 1973, 1974; Bowles \& Gintis, 1976; Thelot, 1982 etc.; Bidwell \& Friedkin, 1988, for a review). It is however only recently that this issue has been broached by economic theory. The influence of the allocation of public funding between basic and advanced education upon growth, welfare and income distribution is analysed by Driskill \& Horowitz (2002) and Su (2004). From a partition between basic and secondary education, the latter being divided into vocational and general studies, Bertocchi \& Spagat (2004) propose a model that determines social stratification at the different stages of economic development. Chusseau \& Hellier (2011) build an intergenerational model with three educational cycles (compulsory basic education, vocational studies and university, with a selection to enter the latter) that can generate very different social stratifications depending (i) on the public funding allocated to each cycle, (ii) on the initial distribution of human capital across dynasties, and (iii) on the severity of the selection procedure. This can engender undereducation traps in which dynasties indefinitely remain at the basic education level.

It is rather easy to generate permanent social stratification from an elitist educational system. However, it can be shown that even with somewhat smooth selection procedures, the division of the educational system into several cycles that bring different human capital levels can generate social stratification and inequality.

Let us firstly assume an elitist education system in which a fixed and limited percentage of the population $\alpha$ is selected at the end of compulsory basic education to enrol in the most prestigious establishments called universities (denoted $U$ ), whereas the rest of the population can choose, either to join the labour market directly, or to enter vocational education establishments (denoted V). The education functions are (i) $\lambda_{i t}=\delta_{B}\left(h_{i t-1}\right)^{\eta}$ in basic education, (ii) $h_{i t}=\lambda_{i t}\left(1+\delta_{V} s_{V i t}{ }^{\varepsilon}\right)$ in vocational studies and (iii) $h_{i t}=\lambda_{i t}\left(1+\delta_{U} s_{U i t}{ }^{\varepsilon}\right)$ in the universities, with $\delta_{U}>\delta_{V}$. At the end of basic education, the individual selects, either to 
work directly, or to pursue higher education by comparing the returns of each possible choice. Her/his income is $\lambda_{i t}$ if $\mathrm{s} /$ he chooses direct working, and $\left(1-s_{j i t}\right) h_{i t}$, when choosing further education of type $j, j=V, U$. Because of the education function, individuals always prefer university to vocational studies. Income maximisation determines the optimal schooling times $\hat{s}_{V}$ and $\hat{s}_{U}$ respectively for vocational studies and university (Appendix 3). These optimal schooling times only depend on the type of study (i.e., on $\delta_{j}, j=V, U$ ). In such an education system, the proportion $\alpha$ of the most educated dynasties go to university, have a human capital and an income higher than other dynasties, and their human capital tends towards the steady state $\hat{h}_{U}=\left(\delta_{B}\left(1+\delta_{U} \hat{S}_{U}^{\varepsilon}\right)\right)^{1 /(1-\eta)}$. The remaining dynasties (in proportion $1-\alpha$ ) follow vocational studies, have lower human capital and incomes, and tend towards the human capital steady state $\hat{h}_{V}=\left(\delta_{B}\left(1+\delta_{V} \hat{S}_{V}^{\varepsilon}\right)\right)^{1 /(1-\eta)}<\hat{h}_{U}$. This model generates a twogroup social stratification. In addition, it is possible to generate a permanent UET in which certain dynasties remain at the basic education level and tend towards the human capital steady state $\hat{h}_{B}=\delta_{B}{ }^{1 /(1-\eta)}$ by adding to the model a fixed cost of further education.

The model presented above is strongly elitist since only a fixed proportion of the individuals with the highest human capital at the end of basic education can go to university. Since these are the children of the most educated individuals of the preceding generation, the dynasties in the elite group remain unchanged from one generation to the next. However, considering the most prestigious universities and their selection procedures, this picture does not fall far short of the reality in a number of countries. In addition, social stratification can be generated with far less severe selection procedures. Suppose for example that a minimum human capital at the end of basic education is a precondition for going to the university, i.e., the general rule in education systems. Young individuals firstly follow compulsory basic education that determines their basic human capital $\lambda_{i t}=\delta_{B}\left(h_{i t-1}\right)^{\eta}$. They can subsequently either directly join the labour market or go to university, which provides human capital $h_{i t}=\lambda_{i t}\left(1+\delta_{U} S_{U i t}{ }^{\varepsilon}\right)$, on condition that their basic human capital is higher than the threshold value $\bar{\lambda}$. Within such a system, everyone wants to go to university but only those with a basic human capital higher than $\bar{\lambda}$ can do so. Since the human capital steady state corresponding to basic education only is $\hat{h}_{B}=\delta_{B}{ }^{1 /(1-\eta)}$, two cases are possible. If $\hat{h}_{B}>\bar{\lambda}$, then all dynasties will sooner or later go to university and they all tend towards the same human capital steady 
state $\hat{h}_{U}=\left(\delta_{B}\left(1+\delta_{U} \hat{s}_{U}^{\varepsilon}\right)\right)^{1 /(1-\eta)}$. In contrast, if $\hat{h}_{B}<\bar{\lambda}$, then all the dynasties with an initial human capital below $\bar{\lambda}$ fall into an under-education trap and tend towards the low skill steady state $\hat{h}_{B}$, and all those with an initial human capital higher than or equal to $\bar{\lambda}$ go to universities and converge to the high skill steady state $\hat{h}_{U}$.

\subsection{History matters}

In the mechanisms triggering under-education traps and social stratifications, the existence and dimension of each social group depend to a large extent on the initial distribution of human capital across dynasties. In addition, any shock that modifies this distribution (migration flows, change in the education system and in the social policy, openness resulting in changes in income distribution etc.) and/or any change in the education policy that modifies the education function have an impact on the social stratification. In a word: history matters.

There is thus a multiplicity of possible steady states depending (i) on the model parameters, and (ii) on the initial distribution of human capital across dynasties. These multiple equilibria approaches comprise Banerjee \& Newman (1993), Galor \& Zeira (1993), Mookherjee \& Ray (2003), Ray (2006), Borissov \& Lambrecht (2009) etc.

In these approaches, there is typically room for structural policies (educational policy, social redistribution, labour market institutions etc.) that can modify social stratification in the direction targeted by the social planner. In particular, if there is a welfare function maximised by the social planner, the latter can adapt its policy if the steady state that derives from the initial situation and the model parameters differs from its objective.

\section{Empirical evidence}

A large body of empirical literature has analysed the impact of parents' earnings and education upon the earnings and educational attainment of their children. In this section, we firstly examine the methodological issues associated with the measurement and estimations of intergenerational mobility in terms of earnings and education. We subsequently set out the main results of the empirical literature on the subject.

This review is centred on advanced economies. This is because (i) the literature is more abundant, more precise and the results more easily comparable for advanced economies, and (ii) the conditions of and returns to education can substantially differ between developed and emerging countries. 
It must be noted that a majority of empirical works on the subject are distinct from theory. Such a lack of theoretical background signifies that the mechanisms underlying the results are not clearly identified. This can lead to different possible interpretations.

\subsection{Methods}

Intergenerational mobility can be approached either in terms of income and earnings or in terms of human capital and educational attainment.

\section{Intergenerational earnings mobility}

The intergenerational income or earnings mobility is typically measured by two indicators, the intergenerational earnings elasticity (IGE) and the intergenerational income correlation (IGC).

The intergenerational earnings elasticity (IGE) $\beta$ is estimated from the following equation:

$$
\log \left(Y_{t}\right)=\alpha+\beta \log \left(Y_{t-1}\right)+\gamma X+\varepsilon
$$

with $Y_{t}$ and $Y_{t-1}$ being respectively the child's and her/his parent's permanent earnings, and $X$ a vector of control variables that are independent from $Y_{t-1}$ and impact on personal income.

The higher the elasticity $\beta$, the lower intergenerational mobility.

The intergenerational correlation (IGC) $\rho$, is defined by:

$$
\rho=\left(\frac{\sigma_{t-1}}{\sigma_{t}}\right) \beta
$$

with $\sigma_{t}$ the standard deviation of $\log$ earnings at generation $t$. As a result, $0<\rho<1$ whereas $\beta$ can be greater than 1 .

The IGC is justified by the fact that a larger deviation in earnings has an impact upon the IGE. It enables this impact to be rectified.

The choice between both measures depends on the objective of the analyst. The IGC is better tailored to study the persistence of income hierarchy whereas the IGE is a better measure of the intergenerational dimension of earnings inequality within a generation.

Finally, the estimate of $\beta$ is biased (i) if the fathers' permanent earnings are incorrectly measured, and (ii) if one does not control for the ages of both the individual and her/his father at the moment when earnings are accounted for. Using a single-year measure as a proxy for permanent earnings induces a substantial downward bias. It is thus necessary to measure permanent earning by the average earnings over several years (Solon, 1992; Zimmerman, 1992; Mazumder 2005). Estimates can also be improved by controlling for the ages of both 
fathers and sons/daughters at the moment when earnings are measured (Haider \& Solon, 2006; Baker \& Solon, 2003; Mazumder, 2005; Grawe, 2006) ${ }^{7}$. In addition, when data on fathers' earnings are missing, these are approximated by fathers' education, professional occupation or social group (Björklund \& Jäntti, 1997; Dearden, Machin \& Reed, 1997). Solon (1999) highlights the fact that these proxies can generate an upward bias in the estimate of $\beta$.

\section{Intergenerational educational mobility}

Intergenerational human capital (or educational) mobility measures the influence of the parents' educational level on their children's educational attainment.

Let us firstly suppose that educational attainment is a continuous variable. Then, as in the case of earnings, intergenerational human capital mobility can be measured by the parentchild regression coefficient or the parent-child correlation.

The intergenerational regression coefficient (IGR) $\beta$ is estimated from equation:

$$
h_{t}=\alpha_{E}+\beta_{E} h_{t-1}+\gamma_{E} X+\varepsilon
$$

with $h_{t}$ and $h_{t-1}$ being respectively the child's and her/his parent's educational attainment, and $X$ a vector of control variables that are independent from $h_{t-1}$ and impact on the educational attainment.

The intergenerational educational correlation (IGEC) $\rho_{E}$ is:

$$
\rho_{E}=\left(\frac{\sigma_{E, t-1}}{\sigma_{E, t}}\right) \beta_{E}
$$

with $\sigma_{E t}$ the standard deviation of education in generation $t$. As for the IGC, $0<\rho_{E}<1$ whereas $\beta_{E}$ can be greater than one.

As the IGC, the IGEC takes into account the difference in educational dispersion between generations. In this respect, it can be noted that the sharp increase in educational attainments in recent decades has been matched by a rise of the variance of education.

If education is a discrete variable, then intergenerational mobility can be measured from transition matrices. These provide the probability for a generation to move from one education level to another. From these matrices, it possible to calculate different indicators to measure different types of social mobility. A 'perfect mobility' means that the parent's skill has no effect on her/his child's skill (see Chevalier et al., 2009).

\footnotetext{
${ }^{7}$ See the survey by Black \& Devereux (2011).
} 


\section{Family characteristics}

The IGE as well as the IGR as determined by relations (8.7) and (8.9) can cover a wide range of family impacts. As underlined in Section 8.2, the impact of the family background combines several mechanisms and channels through which the parents and the family influence the children's educational and professional attainment, and thus her/his income:

1. Intra-family human capital externalities.

2. The parents' income that permits the funding of education.

3. Informational differences that make children from skilled families better equipped to select the best educational strategies.

4. Local externalities and neighbourhood effects that derive from the grouping in the same districts of families with similar educational and income levels.

5. Networks effects for positions and occupations.

6. Health inequalities linked to the parents' educational levels.

7. Genetic transmission of abilities.

The most recent empirical works have attempted to distinguish and identify the impact of each mechanism (see the reviews in Holmlund et al., 2011, Black \& Devereux, 2011, and Björklund \& Jäntti, 2009). Several methods have been implemented for this purpose: analyses using siblings and twins, estimates using adopted children, neighbourhood correlations estimates, instrumental variable estimates, decompositions of intergenerational persistence, use of IQ, analyses of health transmissions, and analyses of intergenerational occupational similarities.

Table 8.2 briefly features each type of analysis by focusing on its objectives and methodological aspects.

Table 8.2 Objectives and methods of the recent empirical works

\begin{tabular}{|c|c|c|}
\hline Type of estimate & Objectives & Methods \\
\hline $\begin{array}{l}\text { Sibling and twin } \\
\text { analyses }\end{array}$ & $\begin{array}{l}\text { To assess the impact of family } \\
\text { backgrounds and genetic } \\
\text { transmission upon the individual's } \\
\text { education and earnings. }\end{array}$ & $\begin{array}{l}\text { 1. Calculation of correlations in earnings } \\
\text { between siblings (and between twins) } j \text { and } \\
j^{\prime}: \operatorname{Corr}\left(y_{i j}, y_{i j^{\prime}}\right)=\operatorname{Cov}\left(y_{i j}, y_{i j^{\prime}}\right) / \sigma_{y}^{2} \text { with } \\
y_{i j} \text { the earnings of individual } j \text { in family } i \text { and } \\
\sigma_{y}^{2} \text { the population earnings variance. High } \\
\text { correlation between siblings shows the impact } \\
\text { of family backgrounds. Higher correlation } \\
\text { between monozygotic twins than between } \\
\text { siblings shows the impact of genetic. } \\
\text { 2. Verification that siblings are more similar } \\
\text { than randomly selected individuals. }\end{array}$ \\
\hline
\end{tabular}




\begin{tabular}{|c|c|c|}
\hline $\begin{array}{l}\text { Analyses using } \\
\text { adoptees }\end{array}$ & $\begin{array}{l}\text { A comparison between adoptees } \\
\text { and non-adoptees children allows a } \\
\text { distinction between the impact of } \\
\text { nurture (education) and nature } \\
\text { (genetics) upon child's earnings and } \\
\text { child's education. }\end{array}$ & $\begin{array}{l}\text { 1. Estimate of bivariate regressions separately } \\
\text { for adopted children and their non-adopted } \\
\text { siblings: } y_{1}=\alpha+\lambda y_{0}+\varepsilon, y_{1} \text { and } y_{0} \text { being } \\
\text { respectively the log earnings or education of } \\
\text { the child and the adoptive parent. If nature } \\
\text { (genetic) is determinant (secondary), } \lambda>0 \\
\text { will be low (high) for adoptees and high (low) } \\
\text { for non-adoptees. } \\
\text { 2. Estimate of multivariate regressions using } \\
\text { adoptees in order to determine what parental } \\
\text { characteristics are determinant. } \\
\text { 3. Regressions on adoptees by using } \\
\text { information on both biological and adoptive } \\
\text { parents. }\end{array}$ \\
\hline $\begin{array}{l}\text { Neighbourhood } \\
\text { correlations }\end{array}$ & $\begin{array}{l}\text { To isolate, within brother } \\
\text { correlations in earnings or in } \\
\text { education, the impact from having } \\
\text { grown up in the same } \\
\text { neighbourhood. }\end{array}$ & $\begin{array}{l}\text { Calculation of correlation }\left(\mathrm{Cov} / \sigma^{2}\right) \text { for } \\
\text { unrelated children living in the same } \\
\text { neighbourhood. A small correlation suggests } \\
\text { that neighbourhood is not a predominant } \\
\text { factor for explaining sibling similarities. }\end{array}$ \\
\hline $\begin{array}{c}\text { Instrumental } \\
\text { variable estimates }\end{array}$ & $\begin{array}{l}\text { To measure the (specific) effect of } \\
\text { parents' income (or education) on } \\
\text { children's income (or education). }\end{array}$ & $\begin{array}{l}\text { To identify a component of parents' income } \\
\text { (or education) that is unrelated with other } \\
\text { parental characteristics (income related to } \\
\text { welfare programs; income shocks due to } \\
\text { labour market status; major educational shift } \\
\text { that influence parents' education). }\end{array}$ \\
\hline IQ and ability & $\begin{array}{l}\text { To assess the genetic transmission } \\
\text { of ability within families. }\end{array}$ & $\begin{array}{l}\text { - Estimation of intergenerational and/or } \\
\text { sibling correlations in cognitive skills } \\
\text { (measured by IQ scores) over time. } \\
\text { - To estimate and compare cognitive and non- } \\
\text { cognitive intergenerational transmission. }\end{array}$ \\
\hline
\end{tabular}

In addition to the determinants directly linked to family characteristics, there are a number of factors that impact educational attainments and intergenerational mobility. These determinants depend on the type of intergenerational mobility (earnings or human capital) that is assessed. In addition, these cannot be limited to those depicted by vector $X$ in equations (8.9) and (8.11) because a number of them are not orthogonal to the parents' human capital and/or income. It is particularly the case of borrowing difficulties that impacts on educational choices and are typically linked to parental income and thereby to parental education level. It can also be the case of certain government policies such as scholarships and other public aids. Concerning human capital mobility, these factors are: educational public expenditures and their allocation between the different education cycles; number of pupils per class and per teacher; earnings of and skills of teachers; geographical distance to school; specific policies (scholarships and terms of award; reduced rate of interests for students etc.); skill and wages if teachers; severity of the selection procedures and changes in educational systems; education costs (fixed and variable) paid by families; imperfections on the credit market, etc. 
Finally, the literature has analysed the existence of intergenerational persistence of earnings and human capital inequalities by focusing on the changes in IGEs and IGRs over time.

\subsection{Income intergenerational mobility}

The now large empirical literature devoted to the estimation of income intergenerational mobility reveals several major features:

1. Intergeneration mobility measured by both IGE and IGC critically differs across countries.

2. The countries with high mobility are more egalitarian than the countries with low mobility. Sweden, Denmark and Finland display lower earnings inequality than the US and the UK, as well as lower intergenerational transmission.

3. Family background factors have a huge impact on earnings, and this impact is higher in the US than in the Nordic countries.

4. A small impact of neighbourhood effects on adult earnings.

5. A rather mixed evidence concerning the existence of credit constraints and of their impacts on adult earnings.

6. Siblings twins and adoptees studies reinforce the diagnosis of a crucial impact of family backgrounds, but they also reveal significant differences across countries.

7. Public expenditure on education particularly on primary education has a material impact on intergenerational mobility of earnings.

\section{Earnings intergenerational elasticities}

Table 8.3 displays the main estimates of father-son IGE of earnings for different countries. The lowest values of father-son earnings IGE are found in Nordic countries and Germany and the highest in the US and Italy. The values found for the UK and France are in between.

Table 8.3 Intergenerational mobility of earnings between fathers and sons (IGEs)

\begin{tabular}{|l|l|l|c|}
\hline \multicolumn{1}{|c|}{ Authors } & \multicolumn{1}{c|}{$\begin{array}{c}\text { Country, Data set, } \\
\text { Years of son's earnings }\end{array}$} & \multicolumn{1}{c|}{ Income } & IGEs \\
\hline \multirow{2}{*}{ Zimmerman (1992) } & US, NLS 1981 & Annual earnings & 0.54 \\
\cline { 3 - 4 } & & Hourly wage & 0.39 \\
\hline \multirow{3}{*}{ Altonji and Dunn (1991) } & \multirow{2}{*}{ US, NLS average of several years } & Father's income & 0.27 \\
\cline { 3 - 4 } & & Annual earnings & 0.18 \\
\cline { 3 - 4 } & Hourly wage & 0.26 \\
\hline Jäntti et al. (2006) & US, NLS 1995 and 2001 & Family income & 0.52 \\
\hline Solon (1992) & US, PSID 1984 & Annual earnings & 0.41 \\
\hline Shea (2000) & US, PSID average of 8 years & Annual earnings & 0.40 \\
\hline Eide \& Showalter (1999) & US, PSID 1991 & Annual earnings & 0.34 \\
\hline Mulligan (1997) & US, PSID average of several years & Annual earnings & 0.32 \\
\hline Couch \& Dunn (1997) & US, PSID average of several years & Annual earnings & 0.13 \\
\hline $\begin{array}{l}\text { Björklung \& Jännti } \\
\text { (1997) }\end{array}$ & US, PSID 1987 & Annual earnings & 0.39 \\
\hline
\end{tabular}




\begin{tabular}{|l|l|l|c|}
\hline $\begin{array}{l}\text { Lee \& Solon (2006, } \\
\text { 2009) }\end{array}$ & US, PSID yearly from 1977 to 2000 & Annual income & 0.44 \\
\hline Mayer \& Lopoo (2004) & US, PSID (cohorts 1949-1965) & Annual income & 0.41 \\
\hline Atkinson et al. (1983) & Britain, a sample of York, 1975-78 & Hourly earnings & 0.42 \\
\hline Dearden et al. (1997) & Britain, NCDS 1991 & Weekly wages & 0.57 \\
\hline Jäntti et al. (2006) & Britain, NCDS 1991 and 2000 & Weekly wages & 0.31 \\
\hline Corak \& Heisz (1999) & Canada income tax records 1994 & Individual income & 0.17 \\
\hline $\begin{array}{l}\text { Lefranc \& Trannoy } \\
\text { (2005) }\end{array}$ & France, FQP 1977, 1985, 1993 & Annual earnings & 0.41 \\
\hline $\begin{array}{l}\text { Jännti \& Österbacka } \\
\text { (1996) }\end{array}$ & Finland, Finnish census 1990 & Annual earnings & 0.22 \\
\hline Österbacka (2001) & Finland, Census, 3-years average & Annual earnings & 0.13 \\
\hline Jäntti et al. (2006) & Finland, Census, 1993 and 2000 & Annual earnings & 0.17 \\
\hline Couch \& Dunn (1997) & Germany, GSEP average of years. & Annual earnings & 0.11 \\
\hline Wiegand (1997) & Germany, GSEP 1994 & Monthly earnings & 0.34 \\
\hline $\begin{array}{l}\text { Björklung \& Jännti } \\
\text { (1997) }\end{array}$ & Sweden, LLS 1990 & Annual earnings & 0.28 \\
\hline Gustafsson (1994) & $\begin{array}{l}\text { Sweden, 222 Stockholm boys, } \\
\text { average of 4 years }\end{array}$ & Market income & 0.14 \\
\hline Österberg (2000) & Sweden, SITR average of 3 years & Annual earnings & 0.13 \\
\hline Jäntti et al. (2006) & Sweden, SITR 1996 and 1999 & Annual earnings & 0.26 \\
\hline
\end{tabular}

Datasets: FQP: Formation et Qualifications Professionnelles. GSEP: German Socio-Economic Panel. LLS: Level of Living Surveys. NCDS: National Child Development Survey. NLS: National Longitudinal Study. PSID: Panel Study of Income Dynamics. SITR: Swedish Income Tax Records.

Sources: For the US: Solon (1999) Tables 3 and 4 except Mayer \& Lopoo (2004) and Lee \& Solon (2006, 2009): compilation by the authors / Other countries: Solon (2002) Table 1, except Lefranc \& Trannoy (2005): compilation by the authors.

In addition, several empirical studies have assessed whether intergenerational mobility has changed over time. For the US, Lee \& Solon (2009) found little evidence of an over-time trend. For the UK, the estimates suggest an increase in earnings IGE for the cohorts born between the late 1950s and the 1970s (Blanden et al., 2004; Nicoletti \& Ermisch, 2007). Lefranc \& Trannoy (2005) find no evidence of a trend for France. In contrast, the intergenerational mobility of earnings seems to have increased in several Nordic countries (Bratberg et al., 2005 for Norway; Pekkala \& Lucas, 2007 for Finland).

Sibling and twin correlations: the impact of family background

The impact of family characteristics on earnings is rather substantial. The correlation of $\log$ earnings between brothers in the US is close to 0.4 . Approximately $40 \%$ of the variation in the permanent earnings is due to a variation in the family characteristics shared by siblings (Solon et al., 1991; Altonji \& Dunn, 1991; Ashenfelter \& Zimmerman, 1997; Solon, 1999; Bjorklund et al., 2002; Mazumder, 2008). Bjorklund et al. (2002) find much lower estimates for Nordic countries (between 0.12 and 0.19 ). This suggests that family background is much more influential in the US than in Nordic countries. 
The correlations in earnings between identical (monozygotic) twins are much higher than those for siblings or for dizygotic twins (Miller et al., 1995 for Australia; Isacsson, 1999 for Sweden; Ashenfelter \& Krueger, 1994, and Rouse, 1997, for the US).

\section{Other determinants}

Neighbourhood effect. Most of the estimates point to limited effects of neighbourhood characteristics upon earnings. Using the US Panel Study of Income Dynamics (PSID), Page \& Solon (2003) find a correlation in adult earnings of 0.16 for unrelated boys in the same neighbourhood, i.e., half of their estimate of the brother correlation. Raaum et al. (2006) estimate neighbourhood correlations in earnings for Norway. They find a very low value of about 0.05 in log earnings for boys. For the city of Toronto, Canada, Oreopoulos (2003) finds neighbourhood correlations close to zero. Consequently, neighbourhood effects do not seem to be a major factor for explaining sibling similarities in adult earnings.

Educational public expenditure. To verify whether countries with better public education systems display lower IGEs, Ichino et al. (2009) correlate estimated intergenerational elasticities of income and public expenditure in education (per student as a percentage of per capita GDP). They find a negative relationship. They also show that the coefficient is higher for public expenditure in primary education: primary education has a crucial impact on the individual educational attainment and thus on the individual earnings. Using the Panel Study of Income Dynamics (PSID), Mayer and Lopoo (2008) find higher IGEs in US States with low per child government expenditure than in States with high per child expenditure.

Educational reforms. The impact of education systems and reforms can be significant. Pekkarinen et al. (2009) studied the impact of the 1970s Finnish educational reform. They find that the reform (i) has lessened the IGE from 0.3 to 0.23 and (ii) has increased educational attainment. According to Machin (2007), the expansion of higher education in the UK in the 1980s and 1990s has significantly increased the proportion of children from high income families with college degrees but far less the proportion of children from low income families. He also finds that earnings mobility has decreased.

Credit constraint. A simple way to study the impact of credit market imperfections consists in identifying groups who are more likely to be credit constrained. The empirical estimates show rather mixed evidence of the impact of credit constraints on earnings intergenerational mobility. Studying the case of Canada, Grawe (2004) makes the assumption that, for any given parental earnings, high ability children are more likely to be credit constrained. He proxies ability by child earnings and uses quantile regression. He finds no evidence for credit constraints. Using wealth data from the US Survey of Income and program Participation 
(SIPP), Mazumder (2005) separates families by net worth ${ }^{8}$. He finds larger IGEs for low net worth families, a group more likely to be borrowing-constrained, but this result is not statistically significant at $5 \%$.

\subsection{Human capital intergenerational mobility}

The empirical literature estimating intergenerational mobility in educational attainment leads to the following diagnosis:

1. Intergeneration mobility measured by both IGR and IGEC critically differs across countries.

2. The countries with high mobility are more egalitarian than the countries with low mobility.

3. The impact of public expenditures on education is significant, but the different dimensions of educational policy produce very uneven impacts.

4. A small impact of neighbourhood effects measured by neighbourhood correlations. However, certain empirical estimates trying to capture neighbourhood effects on educational attainment demonstrate a significant influence.

5. Large effects of parents' income on children's educational attainment.

6. A positive strong influence of early childhood environment and particularly of health.

7. A strong correlation between fathers and sons in terms of professional occupations.

8. The number of pupils per class, particularly in primary school, has a material effect on the child's school performance.

9. A low percentage of youngsters are credit constrained.

10. Empirical estimates prove the existence of inequality traps.

\section{Educational intergenerational elasticities and correlations}

The impact of parents' position on children's attainment has been first estimated by intergenerational elasticities of education. In these works, human capital is typically measured by the number of schooling years, and OLS are used to estimate intergenerational human capital elasticities

Table 8.4. depicts the estimates of IGR for different developed countries. According to these estimates, the US and the UK seem to be less mobile than Germany, France and Nordic countries. This suggests that countries with low social mobility have a higher level of inequality than those with higher social mobility.

\footnotetext{
${ }^{8}$ Net worth measures the ability of parents to borrow against their current wealth or to sell assets in order to finance human capital acquisition for their children (under or over the median net worth).
} 
Table 8.4 Intergenerational coefficients for different countries

\begin{tabular}{|c|c|c|c|c|}
\hline Authors & $\begin{array}{l}\text { Country, } \\
\text { region }\end{array}$ & Data set & $\begin{array}{l}\text { Measures of } \\
\text { human capital }\end{array}$ & $\begin{array}{c}\text { intergenerational } \\
\text { regression coefficient } \\
\text { (IGR) } \\
\end{array}$ \\
\hline $\begin{array}{c}\text { Plug \& } \\
\text { Vijverberg }(2001)\end{array}$ & US, Wisconsin & Wisconsin Longitudinal Survey & Schooling years & $\begin{array}{l}0.227 \text { for father } \\
0.230 \text { for mother }\end{array}$ \\
\hline Mulligan (1997) & US & PSID & Schooling years & $\begin{array}{l}0.32 \text { (father-son) } \\
0.33 \text { (father-child) }\end{array}$ \\
\hline $\begin{array}{c}\text { Berham \& } \\
\text { Taubman (1985) }\end{array}$ & US & $\begin{array}{c}\text { National Academy of Science - } \\
\text { National Research Council (NAS- } \\
\text { NRC) Twin sample }\end{array}$ & Schooling years & $\begin{array}{l}\text { Between } 0.19 \text { and } 0.27 \\
\text { (father-child) }\end{array}$ \\
\hline Olneck (1977) & $\begin{array}{l}\text { US, Michigan, } \\
\text { Kalamazoo }\end{array}$ & $\begin{array}{c}\text { Sample of inhabitants of the city } \\
\text { of Kalamazoo, Michigan }\end{array}$ & Schooling years & 0.45 (father-son) \\
\hline $\begin{array}{l}\text { Dearden et al. } \\
\text { (1997) }\end{array}$ & UK & $\begin{array}{l}\text { National Child development } \\
\text { Survey (NCDS) }\end{array}$ & Schooling years & $\begin{array}{l}0.424 \text { (father-son) } \\
0.415 \text { (father-daughter) }\end{array}$ \\
\hline $\begin{array}{c}\text { Couch \& Dunn } \\
(1997)\end{array}$ & $\begin{array}{l}\text { Germany and } \\
\text { US }\end{array}$ & $\begin{array}{c}\text { German Socio-Economic Panel } \\
\text { (Germany) \& PSID (US) }\end{array}$ & Schooling years & $\begin{array}{l}0.42 \text { for the US and } 0.24 \\
\text { for Germany (father-son) }\end{array}$ \\
\hline $\begin{array}{l}\text { Ben-Halima, } \\
\text { Chusseau \& } \\
\text { Hellier }(2012) \\
\end{array}$ & France & FQP, 1993 and 2003 & $\begin{array}{l}10 \text { educational } \\
\text { levels }\end{array}$ & $\begin{array}{l}0.25 \text { (father-child) } \\
\text { Increase from } 1993 \text { to } \\
2003 \text {. }\end{array}$ \\
\hline $\begin{array}{l}\text { Fabre \& Moullet } \\
(2004)\end{array}$ & France & FQP, 1993 & Schooling years & $\begin{array}{l}0.31 \text { (father-son) } \\
0.29 \text { (mother-son) }\end{array}$ \\
\hline $\begin{array}{l}\text { Holmlund et al. } \\
\qquad(2011)\end{array}$ & Sweden & $\begin{array}{l}\text { Swedish Administrative Records } \\
\text { (SAR) } \\
\text { cohorts born in 1943-1955 S }\end{array}$ & Schooling years & $\begin{array}{l}0.23 \text { (father-child) } \\
0.28 \text { (mother-child) }\end{array}$ \\
\hline $\begin{array}{l}\text { Björklund, } \\
\text { Lindahl and } \\
\text { Plug (2006) }\end{array}$ & Sweden & $\begin{array}{l}\text { (Swedish Administrative } \\
\text { Records) SAR, } 1999\end{array}$ & Schooling years & $\begin{array}{l}0.24 \text { (father-child) } \\
0.24 \text { (mother-child) }\end{array}$ \\
\hline $\begin{array}{l}\text { Black, Devereux, } \\
\text { Salvanes (2005) }\end{array}$ & Norway & $\begin{array}{l}\text { Norweigan Administrative } \\
\text { Records (NAR) }\end{array}$ & Schooling years & $\begin{array}{l}0.22 \text { (father-child) } \\
0.24 \text { (mother-child) }\end{array}$ \\
\hline
\end{tabular}

Intergenerational human capital mobility has also been measured by the intergenerational Education correlation (IGEC). Hertz et al. (2007) provide a survey of correlations and regression coefficients for a sample of 42 developed and developing countries (Table 8.5). The correlations are about 0.4 in Western Europe, between 0.3 and 0.35 in Nordic countries, and equal to 0.46 in the US. These estimates show that Nordic countries have a low educational intergenerational persistence compared to other countries.

Table 8.5 Intergenerational educational persistence

\begin{tabular}{lc}
\hline \multicolumn{1}{c}{ Country } & IGEC \\
\hline Italy & 0.54 \\
US & 0.46 \\
Sweden & 0.40 \\
The Netherlands & 0.36 \\
Norway & 0.35 \\
Finland & 0.33 \\
UK & 0.31 \\
Denmark & 0.30 \\
\hline Source: Hertz et
\end{tabular}

Source: Hertz et al. (2007), Table 2. 
It can be noted that a majority of empirical works measure human capital by the number of schooling years. This measure is disputable because it allocates the same weight to qualitatively different schooling years. Several studies have found decreasing returns to the schooling years (Psacharopoulos, 1994; Wössmann, 2003). Other estimates show that the market value of one schooling year can critically differ depending on the educational cycle and on the type of study (Jarousse \& Mingat, 1986; Ben-Halima et al., 2012).

A key issue is to know whether the general increase in educational attainment has coincided with lower intergenerational persistence. For 42 countries, Hertz et al. (2007) show that regression coefficients (educational intergenerational elasticities) have decreased over time whereas the correlation coefficients show no time trend. Checchi et al. (2008) find that the intergenerational correlation decreased from 0.58 for the cohorts born in 1910-14 to 0.47 for the cohorts born in 1970 or after. Blanden \& Machin (2004) and Machin (2007) find that the expansion of higher education in the UK has favoured children of high income and high education families. Heineck \& Riphahn (2007) find no change in the intergenerational mobility of education in Germany over half a century. Ben-Halima et al. (2012) reveal lower social mobility in France in 2003 compared to 1993, with a critical increase in the influence of the family backgrounds upon the individuals' human capital.

\section{Intergenerational mobility of education measured by transition matrices}

Another way to measure intergenerational transmission of education is to study mobility matrices in order to examine the child's level of education conditional on the human capital of the parent. For a panel of 20 countries, Chevalier et al. (2009) find results that are generally similar to the estimates of intergenerational elasticities or correlations (except for Denmark and Norway which are with the US the countries where the intergenerational link is the strongest).

\section{Decomposition of the family determinants}

IQ and genetics. A recent literature has studied the intergenerational transmission of IQ and cognitive skills and attempted to determine the 'nature' of the transmissions from parents to children (cognitive, non cognitive, genetic etc.). These works reveal (i) that children's IQ are correlated to parents' IQ (Black et al., 2009, for Norway) and (ii) that parents' cognitive abilities matter more for educational attainment whereas non-cognitive abilities matter more for earnings (Gronqvist et al., 2009, for Sweden). 
Nature versus nurture. Sacerdote (2007) uses data from National Longitudinal Survey of Youth (NLSY) to analyse the difference between adoptees and non adoptees ${ }^{9}$. By regressing child's education on mother's education, he finds a higher coefficient for non-adoptees $(0.32)$ than for adoptees (0.09). This suggests that nature could be more important than nurture in determining educational attainment.

Income. From three longitudinal surveys of American high school leavers, Acemoglu \& Pischke (2001) study the effect of family income on children's education, especially on college attendance. The estimates suggest large effects of family income on enrollments: a $10 \%$ increase in family income is associated with a $1.4 \%$ increase in the probability of attending a four-year college. From the French FQP database, Ben-Halima et al. (2012) isolate the impact of father's income on child's educational attainment from the total impact of family background. This accounts for $24.5 \%$ of the total family influence (elasticity) in 2003. They also find that the total impact of the family (father) upon the individuals' education attainments has significantly increased from 1993 to 2003, and that this rise essentially derives from the family's income.

\section{Other determinants}

Public expenditures and education systems. Chevalier et al. (2009) find that intergenerational educational persistence is lower in countries with higher public expenditures for education. From the French FQP database, Ben-Halima et al. (2012) find a strong impact of public expenditure upon child's educational attainment (coefficient equal to 0.67 against 0.25 for the intergenerational coefficient). They also find that both the impacts of educational public expenditure and of the family background have increased between 1993 and 2003. This result suggests that higher public expenditure for education could offset the increasing impact of the family. For Switzerland, Bauer and Riphahn (2009) find that early school starting age increases intergenerational educational mobility. An education policy promoting early school enrolment could reduce intergenerational persistence.

Neighbourhood effect. As for earnings, the neighbourhood correlations are generally low as regards education (lower than 0.2 according to Solon et al., 1997, and of about 0.1 for Solon et al., 2000, for the US; smaller than 0.1 for Norway according to Raaum et al., 2006). It can however be noted that this does not mean that the neighbourhood effect has a negligible effect in the education function.

In the case of France, Goux \& Maurin (2007) find a significant impact of the neighbourhood effect upon children's performance at school.

\footnotetext{
${ }^{9}$ They consider Korean-American adoptees placed with American families between 1970 and 1980.
} 
Burgess \& Briggs (2010) analyze the relations between poverty, location and school assignment in the UK. From the Pupil Level Annual School Census and the National Pupil Database, they estimate the probability of enrolling high-quality schools for poor and nonpoor children. They show that children from poor families are significantly less likely to enroll in high-quality schools.

Credit market imperfections. Some papers have checked the existence of credit constraints. The results show a low percentage of people who are credit constrained. Using data from the US Current Population Survey (CPS), Carneiro \& Heckman (2003) compare the differences in higher education enrolment ( 2 or 4 years in higher education) according to whether parents belong to the earnings lower quartiles. Only 0 to $8 \%$ of young Americans seem to be credit constrained. Dearden et al. (2004) apply the same methodology to Britain and find credit constraints only for small-sized groups within the population.

Number of pupils per class. Using data from the French Ministry of Education for a cohort entering primary education in 1997, Piketty \& Valdenaire (2006) show that a one-unit decrease in the number of pupils per class during the second year of primary school leads to an increase of about 0.3 to 0.4 in the average score in Mathematics at the beginning of the third year, this increase attaining 0.7 for children from low-income families. Consequently, the number of pupils per class has a significant impact for pupils from families with low incomes.

\section{Inequality trap}

From the EHII index which is extend up to $2003,{ }^{10}$ Daymon \& Gimet (2007) verify the existence of inequality traps at the international level. They show the existence of inequality traps and highlight the significant influence of the credit market, wealth and access to the initial levels of education on educational attainment.

\section{Conclusion}

We have reviewed the economic literature that analyses the relations between education and intergenerational mobility, and their impact on inequality persistence.

From a theoretical point of view, the early literature diagnosed a convergence in the educational level of the dynasties in the long term. This diagnosis has subsequently been

\footnotetext{
${ }^{10}$ Estimation of the Household Inequality and Inequity Index from Galbraith and Kum (2003) database that provides data from 1963 to 1999 for 71 countries. Extension using UTIP-UNIDO (University of Texas Inequality Project and United Nations Industrial Development Organization) Database.
} 
revisited and the emerging of social stratification and under education traps has been analysed. These stratifications and traps may be caused by a series of factors and/or of their combination: fixed costs of education, credit constraint, local externalities and neighbourhood effects, S-shape education function, educational systems etc. Finally, this literature comes to the conclusion that history matters.

The empirical literature has ventured to measure the contribution of the different factors that influence intergenerational mobility in earnings and educational attainment. All the studies underline the importance of family backgrounds with albeit significantly dissimilar impacts across countries. In addition, the most recent literature has attempted to disentangle the different components of the family influence: education, income, genetically transmitted ability, neighbourhood, health etc. Public educational expenditure also has a significant impact. The results are more ambiguous concerning neighbourhood effects and credit constraints.

One of the main challenges for future researches is to reunite empirical works and theoretical approaches. In fact, these two sets of literature have tended to develop independently, with the search for new data and empirical methods on the one side, and increasingly sophisticated modelling on the other. Many mechanisms from the theoretical literature have not been tested empirically and a number of empirical results have no clear theoretical bases and thus may derive different interpretations.

\section{Appendix 1}

1. Determination of the optimal education expense by maximising the net lifetime income We denote $\rho_{t} \equiv 1+r_{t}$.

$$
\begin{gathered}
I_{i t}=h_{i t}-\rho_{t} e_{i t} ; \partial I_{i t} / \partial e_{i t}=\lambda \delta e_{i t}^{\lambda-1}\left(h_{i t-1}\right)^{\eta}-\rho_{t}=0 \\
e_{i t}=\left(\frac{\lambda \delta}{\rho_{t}}\right)^{1 /(1-\lambda)}\left(h_{i t-1}\right)^{\eta /(1-\lambda)} \\
h_{i t}=\delta^{1 /(1-\lambda)}\left(\lambda \rho_{t}^{-1}\right)^{\lambda /(1-\lambda)}\left(h_{i t-1}\right)^{\eta /(1-\lambda)}
\end{gathered}
$$

\section{Determination of the credit supply}

Individual $(i, t)$ 's credit supply is $\rho_{t+1}^{-1} c_{r i t}$, i.e., the amount of income that must be saved and lent during her/his active period to fund the consumption $c_{r i t}$ of the retirement period.

The individual's maximisation programme is: 


$$
\max _{c_{\text {ait }}, c_{r i t}} u_{i t}=(1-\sigma) \log c_{\text {ait }}+\sigma \log c_{r i t} \text {, s.t. } h_{i t}=\rho_{t} e_{i t}+c_{\text {ait }}+\rho_{t+1}{ }^{-1} c_{r i t}
$$

We insert $c_{\text {ait }}$ from the constraint into the utility function.

The first order condition $\frac{\partial u}{\partial c_{r i t}}=-\frac{(1-\sigma) \rho_{t+1}^{-1}}{h_{i t}-\rho_{t} e_{i t}-\rho_{t+1}^{-1} c_{r i t}}+\frac{\sigma}{c_{r i t}}=0$ entails $c_{r i t}=\rho_{t+1} \sigma\left(h_{i t}-\rho_{t} e_{i t}\right)$

Thus $\rho_{t+1}{ }^{-1} c_{r i t}=\sigma I_{i t}$, where $I_{i t}=h_{i t}-\rho_{t} e_{i t}$ is the net income of individual $(i, t)$.

\section{Determination of the interest rate}

The credit supply of individual $(i, t-1)$, i.e. individual $(i, t)$ 's parent, is $\rho_{t}^{-1} c_{r i t-1}=\sigma I_{i t-1}$, and the total supply for credit of generation $\mathrm{t}-1$ is thus $\sigma I_{t-1}=\sigma \sum_{i=1}^{M} I_{i t-1}$

The demand for credit of individual $(i, t)$ is $e_{i t}=\left(\lambda \rho_{t}^{-1} \delta\right)^{1 /(1-\lambda)}\left(h_{i t-1}\right)^{\eta /(1-\lambda)}$, and the total demand for credit of generation $t$ is $E_{t}=\sum_{i} e_{i t}=\left(\lambda \rho_{t}^{-1} \delta\right)^{1 /(1-\lambda)} \sum_{i}\left(h_{i t-1}\right)^{\eta /(1-\lambda)}$.

The equilibrium interest rate $\rho_{t}$ that clears the market for credit is:

$$
\rho_{t}=\lambda \delta\left(\frac{\sum_{i}\left(h_{i t-1}\right)^{\eta /(1-\lambda)}}{\sigma I_{t-1}}\right)^{1-\lambda}
$$

\section{The steady state}

From $(8 \mathrm{~A} 1),(8 \mathrm{~A} 2)(8 \mathrm{~A} 3): \hat{h}=\delta^{1 /(1-\eta)} \hat{e}^{\lambda /(1-\eta)} ; \hat{e}=\left(\lambda \delta \hat{h}^{\eta} / \hat{\rho}\right)^{1 /(1-\lambda)} ; \hat{\rho}=\lambda \delta\left(\frac{\hat{h}^{\eta /(1-\lambda)}}{\sigma(\hat{h}-\hat{\rho} \hat{e})}\right)^{1-\lambda}$

Thus: $\hat{e}=\delta^{\frac{1}{1-\lambda-\eta}}(\lambda / \hat{\rho})^{\frac{1-\eta}{1-\lambda-\eta}} ; \hat{h}=\delta^{\frac{1}{1-\lambda-\eta}}(\lambda / \hat{\rho})^{\frac{\lambda}{1-\lambda-\eta}} ; \hat{\rho}=\max \left\{1, \frac{\lambda}{\left(\sigma\left(1-\lambda^{1-\lambda}\right)\right)^{1 /(1-\lambda)}}\right\}$

\section{Appendix 2}

The maximisation programme $\max _{s_{i t}} I_{i t}=\left(1-s_{i t}\right)\left(1+\delta s_{i t}{ }^{\varepsilon}\left(h_{i t-1}\right)^{\eta}\right)$ provides individual i's optimal schooling time $\hat{s}_{i t}$, which is the solution to the equation:

$$
\left(h_{i t-1}\right)^{\eta}=\left(\varepsilon \delta s_{i t}{ }^{\varepsilon-1}-(1+\varepsilon) \delta s_{i t}{ }^{\varepsilon}\right)^{-1}
$$

It can easily be verified that: $\partial \hat{s}_{i t} / \partial h_{i t-1}>0$. 
If there is a schooling time steady state $\hat{s}$, then at this steady state $h_{i t}=\delta \hat{s}^{\varepsilon}\left(h_{i t-1}\right)^{\eta}, \forall i$, which generates the human capital steady state $\hat{h}=\left(\delta \hat{s}^{\varepsilon}\right)^{1 /(1-\eta)}$. By combining (8A4) with $h_{t}=\delta \hat{s}^{\varepsilon}\left(h_{t-1}\right)^{\eta}$, this yields the following equation that determines a unique steady state $\hat{s}$ :

$$
(1+\varepsilon) s+\delta^{-1 /(1-\eta)} s^{(1-\eta-\varepsilon) /(1-\eta)}-\varepsilon=0
$$

\section{Appendix 3}

$$
\begin{aligned}
& h_{i t}(j)=\lambda_{i t}\left(1+\delta_{j} s_{j, i t}{ }^{\varepsilon}\right), j=V, U \\
& I_{i t}=\left(1-s_{j, i t}\right) \lambda_{i t}\left(1+\delta_{j} s_{j, i t}{ }^{\varepsilon}\right) \\
& \partial I_{i t} / \partial s_{i t, j}=-\lambda_{i t}+\varepsilon \lambda_{i t} \delta_{j} s_{j, i t}{ }^{\varepsilon-1}-(1+\varepsilon) \lambda_{i t} \delta_{j} s_{j, i t}{ }^{\varepsilon} \\
& (1+\varepsilon) \delta_{j} s_{j}+s_{j}{ }^{1-\varepsilon}-\varepsilon \delta_{j}=0 \\
& z\left(s_{j}\right)=(1+\varepsilon) \delta_{j} s_{j}+s_{j}{ }^{1-\varepsilon}-\varepsilon \delta_{j}=0, \\
& \frac{\partial z}{\partial s_{j}}>0 ; s_{j}=0 \Rightarrow z=-\varepsilon \delta_{V} ; s_{i t}=1 \Rightarrow z=1+\delta_{j} \\
& \Rightarrow \exists \hat{s}_{j} \text { unique s.t. } z\left(s_{j}\right)=0
\end{aligned}
$$

By inserting $\lambda_{i t}=\delta_{B}\left(h_{i t-1}\right)^{\eta}$ into $h_{i t}=\lambda_{i t}\left(1+\delta_{j} \hat{s}_{j}{ }^{\varepsilon}\right)$, we determine the stable steady state $(0<\eta<1): \quad \hat{h}_{j}=\left(\delta_{B}+\delta_{B} \delta_{j} \hat{s}_{j}^{\varepsilon}\right)^{1 /(1-\eta)}, j=V, U$

\section{References}

Acemoglu, D. and J.S. Pischke (2001) 'Changes in the wage structure, family income, and children's education', European Economic Review, 45, 890-904.

Altonji, J.G. and T.A. Dunn (1991) 'Relationships among the Family Incomes and Labor Market Outcomes of Relatives', Research in Labor Economics, 12, 269-310.

Anderson, C.A. (1961) 'A skeptical note on the relation of vertical mobility to education', American Journal of Sociology, 66(6), 560-570.

Ashenfelter, O and A.B. Krueger (1994) 'Estimates of the Returns to Schooling from a New Sample of Twins', American Economic Review, 84(5), 1157-73.

Ashenfelter, O. and D. Zimmerman (1997) 'Estimates of the economic returns to schooling from sibling data: fathers, sons and brothers', Review of Economics and Statistics, 79, 1-9.

Atkinson, A.B., A.K. Maynard and C.G. Trinder (1983) Parents and Children: Incomes in Two Generations (London: Heinemann).

Baker, M. and G. Solon (2003) 'Earnings dynamics and inequality among Canadian men, 1976-1992', Journal of Labor Economics, 21, 289-321.

Banerjee, A. and A. Newman (1993) 'Occupational choice and the process of development', Journal of Political Economy, 101(2), 274-98.

Barham, V., R. Boadway, M. Marchand and P. Pestieau (1995) 'Education and poverty trap', European Economic Review, 39(7), 1257-1275.

Baudelot, C. and R. Establet (1971) L'école capitaliste en France (Paris : Maspero).

Bauer, P.C. and R.T. Riphahn (2009) 'Kindergarten enrolment and the intergenerational transmission of education', IZA Discussion paper, No. 4466, Bonn.

Becker, G. and N. Tomes (1976) 'Child endowments and the quantity and quality of children', Journal of Political Economy, 84, S143-S162. 
Becker, G. and N. Tomes (1979) 'An equilibrium theory of the distribution of income and intergenerational mobility', Journal of Political Economy, 87(6); 1153-89.

Becker, G. and N. Tomes (1986) 'Human capital and the rise and fall of families', Journal of Labor Economics, 4(3), S1-39.

Behrman, J. and P. Taubman (1985) 'Intergenerational Earnings Mobility in the United States: Some Estimates and a Test of Becker's Intergenerational Endowments Model', Review of Economics and Statistics, 67, 141-51.

Benabou, R. (1993) 'Workings of a city: location, education and production', Quarterly Journal of Economics, 108, 619-52.

Benabou, R. (1994) 'Human capital, inequality, and growth: A local perspective', European Economic Review, 38, 817-26.

Benabou, R. (1996a) 'Inequality and Growth', NBER Macroeconomics Annual, 11, 11-74.

Benabou, R. (1996b) 'Heterogeneity, stratification and growth: macroeconomic implications of community structure and school finance', American Economic Review, 86, 584-609.

Benabou, R. (1996c) 'Equity and efficiency in human capital investment: the local connection', Review of Economic Studies, 63, 237-64.

Ben-Halima, B., N. Chusseau and J. Hellier (2012) 'Skill Premia and Intergenerational Skill Transmission: The French Case', EQUIPPE Working Paper, University of Lille 1.

Bertocchi, G. and M. Spagat (2004) 'The evolution of modern educational systems. Technical versus general education, distributional conflict, and growth', Journal of Development Economics, 73, 55982 .

Bidwell, C.E. and N.E. Friedkin (1988) 'The sociology of Education' in: Smelser N. (ed.) Handbook of Sociology (Newbury Park: Sage Publications).

Björklund, A. and M. Jäntti (1997) 'Intergenerational Income Mobility in Sweden Compared to the United States', American Economic Review, December, 87(5), 1009-18.

Björklund, A. and M. Jäntti (2009) 'Intergenerational income mobility and the role of family background', in: W. Salverda, B. Nolan and T. Smeeding (eds.) Handbook of Economic Inequality (Oxford: Oxford University Press).

Björklund, A., M. Lindahl and E. Plug (2006) 'The Origins of Intergenerational Associations: Lessons from Swedish Adoption Data', Quarterly Journal of Economics, 121(3), 999-1028.

Björklund, A., T. Eriksson, M. Jäntti, O. Raaum and E. Österbacka (2002) 'Brother correlations in earnings in Denmark, Finland, Norway and Sweden compared to the United States', Journal of Population Economics, 15, 757-72.

Black, S. and P. Devereux (2011) 'Recent Developments in Intergenerational Mobility' in: O. Ashenfelter and D. Card (eds.) Handbook of Labor Economics 4B (Amsterdam: Elsevier, NorthHolland), 1487-541.

Black, S.E., P.J. Devereux and K.G. Salvanes (2005) 'Why the apple doesn't fall far: Understanding intergenerational transmission of human capital', American Economic Review, 95, 437-49.

Black, S.E., P.J. Devereux and K.G. Salvanes (2009) 'Like father, like son? A note on the intergenerational transmission of IQ scores', Economics Letters, 105, 138-40.

Blanden, J., A. Goodman, P. Gregg and S. Machin (2004) 'Changes in intergenerational mobility in Britain' in: M. Corak (ed.) Generational Income Mobility in North America and Europe (Cambridge University Press).

Borissov, K. and S. Lambrecht (2009) 'Growth and Distribution in an AK-Model with Endogenous Impatience', Economic Theory, 39(1), 93-112.

Boudon, R. (1973) L'inégalité des chances, Paris: Armand Colin. English edition: 1974, Education, Opportunity, and Social Inequality: Changing Prospects in Western Society (New York: WileyInterscience).

Bourdieu, P. and J.-C. Passeron (1970) La reproduction. Eléments pour une théorie du système d'enseignement (Paris : Editions de minuit). English edition: 1990, Reproduction in Education, Society and Culture (London: Sage).

Bowles, S. and H. Gintis (1976) Schooling in capitalist America: Educational reform and the contradictions of economic life (New York: Basic Books).

Bratberg, E., O.A. Nielsen and K. Vaage (2005) 'Intergenerational earnings mobility in Norway: levels and trends', Scandinavian Journal of Economics, 107, 419-35. 
Burgess, S. and A Briggs (2010) 'School assignment, school choice and social mobility', Economics of Education Review, 29(4), 639-49.

Cahuc, P., S. Carcillo, O. Galland and A. Zylberberg (2011), La machine à trier (Paris: Eyrolles).

Carneiro, P. and J. Heckman (2003) 'Human Capital Policy', NBER Working Paper, No. 9495, Cambridge, MA.

Checchi, D., C. Fiorio, and M. Leonardi (2008) 'Intergenerational persistence in educational attainment in Italy', IZA Discussion Paper, No. 3622, Bonn.

Chevalier, A., K. Denny, and D. McMahon (2009) 'A Multi-country study of inter-generational educational mobility' in: P. Dolton, R. Asplundh and E. Barth (eds.) Education and inequality Across Europe (London: Edward Elgar).

Chusseau N. and J. Hellier (2011) 'Educational systems, intergenerational mobility and social segmentation', European Journal of Comparative Economics, 8(2), 255-86.

Corak, M. and A. Heisz (1999) 'The intergenerational earnings and income mobility of Canadian Men', Journal of Human Resources, 34, 504-33.

Couch, K.A. and T.A. Dunn (1997) 'Intergenerational Correlations in Labor Market Status: A Comparison of the United States and Germany', Journal of Human Resources, 32(1), 210-32.

Dale, S. and A. Krueger (2002) 'Estimating the payoff to attending a more selective college: An application of selection on observables and unobservables', Quarterly Journal of Economics, 117(4), 1491-527.

Daniel, K., D. Black and J. Smith (1995) College quality and the wages of young men (University of Western Ontario).

Daymon, C. and C. Gimet (2007) 'An empirical test of the inequality traps concept', University of the Mediterranean, Document de travail CEFI.

Dearden, L., McGranahan L. and B. Sianesi (2004) 'The role of credit constraints in educational choices: evidence from the NCDS and BCS70', Centre for the Economics of Education Working Paper, No. 48, London School of Economics.

Dearden, L., S. Machin and H. Reed (1997) 'Intergenerational Mobility in Britain', Economic Journal, 107(440), 47-66.

Driskill, R.A. and A. Horowitz (2002) 'Investment in Hierarchical Human Capital', Review of Development Economics, 6(1), 48-58.

Durlauf, S. (1994) 'Spillovers, stratification, and inequality', European Economic Review, 38(3-4), 836-45.

Durlauf, S. (1996) 'A Theory of Persistent Income Inequality', Journal of Economic Growth, 1, 75-93.

Eide, E.R. and M.H. Showalter (1999) 'Factors Affecting the Transmission of Earnings Across the Generations: A Quantile Regression Approach', Journal of Human Resources, 34, 253-67.

Fabre, A. and S. Moullet (2004) 'Externalités de l'éducation et mobilité intergénérationnelle: application au cas français', Economie et Prévision, 5(166), 19-37.

Galbraith, J.K. and H. Kum (2003) 'Inequality and Economic Growth. A Global View based on Meausures of Pay', CESifo Economic Studies, 49(4), 527-56.

Galor, O. and D. Tsiddon (1997) 'The distribution of human capital and economic growth', Journal of Economic Growth, 2, 93-124.

Galor, O. and J. Zeira (1993) 'Income distribution and macroeconomics', Review of Economic Studies, $60,35-52$.

Goux, D. and E. Maurin (2007) 'Close neighbours matter: Neighbourhood effects on early performance at school', Economic Journal, 117, 1-24.

Gradstein, M. and M. Justman (2002) 'Education, Social Cohesion, and Economic Growth', American Economic Review, 92(4), 1192-204.

Grawe, N.D. (2004) 'Reconsidering the use of nonlinearities in intergenerational earnings mobility as a test for credit constraints', Journal of Human Resources, 39, 813-27.

Grawe, N.D. (2006) 'The extent of lifecycle bias in estimates of intergenerational earnings persistence', Labour Economics, 13, 551-70.

Gronqvist, E., B. Ockert, and J. Vlachos (2009) 'The Intergenerational transmission of cognitive and non-cognitive abilities', Mimeo.

Gustafsson, B. (1994) 'The Degree and Pattern of Income Immobility in Sweden', Review of Income and Wealth, Series 40, 67-86. 
Haider, S.J. and G. Solon (2006) 'Life-cycle variation in the association between current and lifetime earnings', American Economic Review, 96, 1308-20.

Heineck, G. and R.T. Riphahn (2007) 'Intergenerational transmission of educational attainment in

Germany: The last five decades', IZA Discussion Paper, No. 2985, Bonn.

Hertz, T., T. Jayasundera, P. Piraino, S. Selcuk, N. Smith and A. Verashchagina (2007) 'The inheritance of educational inequality: International comparisons and fifty-year trends', The B.E. Journal of Economic Analysis \& Policy, No. 7, Article 10.

Holmlund, H., M. Lindahl and E. Plug (2011) 'The Causal Effect of Parent's Schooling on Children's Schooling: A Comparison of Estimation Methods', Journal of Economic Literature, 49(3), 615-51.

Ichino A., L. Karabarbounis and E. Moretti (2009) 'The political economy of intergenerational income mobility', IZA Discussion Paper, No. 4767, Bonn.

Isacsson, G. (1999) 'Estimates of the Return to Schooling in Sweden from a Large Sample of Twins', Labour Economics, 6(4), 471-89.

Jännti, M. and E. Österbacka (1996) 'How much of the variance in income can be attributed to family background? Empirical Evidence from Finland', Mimeo.

Jäntti, M., B. Bratsberg, K. Røed, O. Raaum, R. Naylor, E. Österbacka, A. Björklund and T. Eriksson (2006) 'American exceptionalism in a new light: A comparison of intergenerational earnings mobility in the Nordic countries, the United Kingdom and the United States', IZA Discussion Paper, No. 1938, Bonn.

Jarousse, J.P. and A. Mingat (1986) 'Un réexamen du modèle de gains de Mincer', Revue Economique, 37(6), 999-1031.

Kerckhoff, A.C. (2000) 'Transition from school to works in comparative perspective' in: M.T. Hallinan (ed.) Handbook of the Sociology of education (New York: Kluwer Academic/Plenum Publishers), 253-74.

Lee, C.-I. and G. Solon (2006) 'Trends in Intergenerational Income Mobility', NBER Working Paper, No. 12007.

Lee, C.-I. and G. Solon (2009) 'Trends in intergenerational income mobility', Review of Economics and Statistics, 91(4), 766-72.

Lefranc, A. and A. Trannoy (2005) 'Intergenerational earnings mobility in France: Is France more mobile than the US?', Annales d'Economie et de Statistique, 78, 57-77.

Loury, G. (1981) 'Intergenerational transfers and the distribution of earnings', Econometrica, 49(4), 843-67.

Machin, S. (2007) 'Education expansion and intergenerational mobility in Britain' in: L. Woessman and P. Peterson (eds.) Schools and the equal opportunity problem (MIT Press).

Maoz, Y.D. and O. Moav (1999) 'Intergenerational mobility and the process of development', The Economic Journal, 109(458), 677-98.

Mayer, S.E. and L.M. Lopoo (2004) 'What Do Trends in the Intergenerational Economic Mobility of Sons and Daughters in the United States Mean?', in: M. Corak (ed.) Generational income mobility in North America and Europe (Cambridge: Cambridge University Press), 2004, 90-121.

Mayer, S.E. and L.M. Lopoo (2008) 'Government spending and intergenerational mobility', Journal of Public Economics, 92, 139-58.

Mazumder B. (2005) 'Fortunate sons: New estimates of intergenerational mobility in the U.S. using social security earnings data', Review of Economics and Statistics, 87, 235-55.

Mazumder, B. (2008) 'Sibling similarities and economic inequality in the US', Journal of Population Economics, 21, 685-701.

Miller P., C. Mulvey and N. Martin (1995) 'What do twins studies reveal about the economic returns to education? A comparison of Australian and U.S. findings', American Economic Review, 85, 58699.

Moav O. and Z. Neeman (2012) 'Saving Rates and Poverty: The Role of Conspicuous Consumption and Human Capital, The Economic Journal, DOI: 10.1111/j.1468-0297.2012.02516.x

Mookherjee, D. and D. Ray (2003) 'Persistent inequality', Review of Economic Studies, 70(2), 369-93.

Mulligan C.B (1997) Parental priorities and economic inequality (Chicago: University of Chicago Press).

Nicoletti, C. and J. Ermisch (2007) 'Intergenerational earnings mobility: Changes across cohorts in Britain', The B.E. Journal of Economic Analysis and Policy, 7, Article 9. 
Olneck, M.R. (1977) 'On the use of sibling data to estimate the effects of family background, cognitive skills and schooling: results from the Kalamazoo brothers study' in: P. Taubman (ed.) Kinometrics: determinants of socioeconomic success within and between families (Amsterdam: North-Holland).

Ono, H. (2004) 'College quality and earnings in the Japanese labor market', Industrial Relations, 43(3), 595-617.

Oreopoulos, P. (2003) 'The long-run consequences of growing up in a poor neighbourhood', Quarterly Journal of Economics, 118, 1533-75.

Österbacka, E. (2001) 'Family background and economic status in Finland', Scandinavian Journal of Economics, 103, 467-84.

Österberg, T. (2000) 'Intergenerational income mobility in Sweden: What do tax data show?', Review of Income and Wealth, 46, 421-36.

Page, M.E. and G. Solon (2003) 'Correlations between brothers and neighboring boys in their adult earnings: The importance of being urban', Journal of Labor Economics, 21, 831-55.

Pekkala, S. and R.E.B. Lucas (2007) 'Differences across cohorts in Finnish intergenerational income mobility', Industrial Relations, 46, 81-111.

Pekkarinen, T., R. Uusitalo and S. Kerr (2009) 'School tracking and intergenerational income mobility: Evidence from the Finnish comprehensive school reform', Journal of Public Economics, 93, 965-73.

Piketty, T. (2000) 'Theories of Persistent Inequality and Intergenerational Mobility' in: A. Atkinson and F. Bourguignon (eds.) Handbook of Income Distribution (Amsterdam: Elsevier), 429-76.

Piketty, T. and M. Valdenaire (2006) 'L'impact de la taille des classes sur la réussite scolaire dans les écoles, collèges et lycées français. Estimations à partir du panel primaire 1997 et du panel secondaire 1995', Les dossiers du Ministère de l'Education Nationale, de l'Enseignement Supérieur et de la Recherche - Enseignement scolaire, Mars.

Plug E. and W. Vijverberg (2001) 'Schooling, family background, and adoption: does family income matter?', IZA Discusison Paper, No. 246.

Psacharopoulos, G. (1994) 'Returns to investment in education: a global update', World Development, $22,1325-43$.

Raaum ,O., K.G. Salvanes and E.O. Sorensen (2006) 'The neighborhood is not what it used to be', Economic Journal, 116, 200-22.

Ray, D. (2006) 'On the dynamics of inequality', Economic Theory, 29, 291-306.

Rouse, C.E. (1997) 'Further estimates of the economic return to schooling from a new sample of twins', Working Paper No. 388, Industrial Relations Section, Princeton University.

Sacerdote, B. (2007) 'How large are the effects from changes in family environment? A study of Korean American adoptees', Quarterly Journal of Economics, 122, 119-57.

Shavit, Y. and W. Muller (2000) 'Vocational secondary education, Tracking, and social stratification' in: M.T. Hallinan (ed.) Handbook of the Sociology of education (New York: Kluwer Academic/Plenum Publishers).

Shea, J. (2000) 'Does Parents' Money Matter?', Journal of Public Economics, 77, 155-84.

Solon, G. (1992) 'Intergenerational income mobility in the United States', American Economic Review, 82, 393-408.

Solon, G. (1999) 'Intergenerational mobility in the labor market' in: O. Ashenfelter and D. Card (eds.) Handbook of Labor Economics 3 (Amsterdam: North-Holland), 1761-800.

Solon, G. (2002) 'Cross-Country Differences in Intergenerational Earnings Mobility', Journal of Economic Perspectives, 16(3), Summer, 59-66.

Solon, G., M. Page, and G. Duncan (2000) 'Correlations between Neighboring Children in Their Subsequent Educational Attainment', Review of Economics and Statistics, 82(3), 383-92.

Solon, G., M. Corcoran, R.B. Gordon and D. Laren (1991) 'A longitudinal analysis of sibling correlations in economic status', Journal of Human Resources, 23, 388-96.

Sorokin, P. (1959) Social and cultural mobility (Glencoe, IL, Free Press).

$\mathrm{Su}, \mathrm{X}$. (2004) 'The allocation of public funds in a hierarchical educational system', Journal of Economic Dynamics \& Control, 28, 2485-510.

Thelot, C. (1982) Tel père, tel fils. Position sociale et origine familiale, (Paris : Dunod).

Weber, M. (1906, first edition), 1946 Edition: The theory of social and economic organisation, (Glencoe, IL, Free Press). 
Wiegand, J. (1997) 'Intergenerational Earnings Mobility in Germany', University College London, Mimeo.

Wössmann, L. (2003) 'Specifying human capital', Journal of Economic Surveys, 17(3), 239-70.

Zimmerman, D.J. (1992) 'Regression toward mediocrity in economic stature', American Economic Review, 82, 409-29. 